\title{
Antiandrogenic and Estrogenic Compounds: Effect on Development and Function of Male Reproductive System
}

\author{
Anna Hejmej, Małgorzata Kotula-Balak and Barbara Bilińska \\ Department of Endocrinology, Institute of Zoology, Jagiellonian University
}

Poland

\section{Introduction}

In the last 50 years the increase in the frequency of male reproductive abnormalities has been observed in human (Auger et al., 1995; Bergström et al., 1996; Carlsen et al., 1992; Skakkebaek et al., 2001; Thonneau et al., 2003). Epidemiological studies have shown increasing trends in the incidence of cryptorchidism (undescended testis) and hypospadias (abnormal location of the urethral opening) in several regions of Australia, Europe, and the United States (Acerini et al., 2009; Boisen et al., 2004; Källén et al., 1986; Nassar et al., 2007; Paulozzi, 1999; Toppari et al., 2001). Moreover, several reports indicated that semen quality have declined during last century (Auger et al., 1995; Carlsen et al., 1992; Swan et al., 2000; Sharpe \& Irvine, 2004). Decreasing sperm concentration and percentage of motile spermatozoa, and increasing number of spermatozoa with morphological alterations were observed in European population between 1940 and 1990. For instance, it has been found that the prevalence of an abnormally low sperm count in young men reaches even $15-20 \%$ (Andersson et al., 2008; Jørgensen et al., 2006, 2011). In earlier study by Jørgensen et al. (2001) significant geographical variations in semen quality have been also described. Although, the reason for these regional differences is not fully elucidated, some data indicate that a correlation exists between impaired semen quality and exposure to pesticides used in agricultural areas (Swan et al., 2003). Interestingly, it has been noticed that in the industrial areas, where peoples are exposed to high levels of industrial chemicals, the birth sex ratio can be altered; in some region of Canada male birth sex ratio (i.e. number of male births per total number of births) have reached only 0.3 during the period $1990-2003$ (Mackenzie et al., 2005).

In 2001 Skakkebaeck and co-workers have suggested that cryptorchidism, hypospadias, testicular cancer and oligozoospermia are interrelated disorders comprising a single syndrome, called the testicular dysgenesis syndrome (TDS) (Skakkebaeck et al., 2001; Skakkebaeck \& Jørgensen, 2005). This idea arose from the observation that cryptorchidism and hypospadias are closely linked to testicular cancer, because in men with a history of one of these anomalies significantly increased risk of testicular cancer was described (Davenport et al., 1997; Dieckmann \& Pichlmeier, 2004; Sharpe \& Irvine, 2004). Moreover, oligozoospermia is frequently found in men, who develop testicular cancer (Møller \& Skakkebaek, 1999). The disorders included in TDS are believed to result from disruption of 
hormone synthesis or action during fetal development of reproductive system. Indeed, numerous experimental studies have demonstrated that prenatal exposure to some environmental chemicals may disrupt the endocrine system in males and thus interfere with hormone-dependent development (Delbès et al., 2006; Fisher, 2004a; Gray et al., 2006).

Male reproductive system anomalies have been also reported in wild living animals (Vos et al., 2000). In fish, sexual reversal, decreased sperm count and motility, and spermatogenesis impairment were noticed (Barnhoorn et al., 2004; Jobling et al., 2002; Vajda et al., 2008). Feminization and abnormal gonadal development were observed in reptiles and birds (De Solla et al., 1998, 2006; Fry, 1995; Guillette et al., 1994), whereas in mammals, such as panthers or polar bears cryptorchidism and reduced size of reproductive organs were found (Mansfield \& Land, 2002; Sonne et al., 2006). An interesting example of the species in which environmental pollutants may be the cause of reproductive system abnormalities is Sitka Black-Tailed Deer. It was reported that in the population living in the Aliulik Peninsula of Kodiak Island extraordinary high percentage $(75 \%)$ of the males exhibited cryptorchidism when compared with males living elsewhere on the Kodiak Archipelago, among which only 12\% were cryptorchid (Bubenik et al., 2001; Veeramachaneni et al., 2006a). Additionally, abnormal antlers and testicular neoplasia were frequently observed in cryptorchid deer from Aliulik Peninsula. The authors hypothesized that it was likely that testis and antler dysgenesis resulted from exposure of pregnant female (or alternatively, historic exposure of founders) to some estrogenic endocrine disrupting agent(s) present in the environment (Veeramachaneni et al., 2006a).

Although the substances affecting endocrine system were studied from 1950', the term "endocrine disruptor" was introduced in 1991 at Wingspread Conference, organized to evaluate the adverse effects observed in wildlife in the Great Lakes region in North America (Colborn \& Clement, 1992; Colborn et al., 1993). According the World Health Organization (2006) endocrine disruptor (ED) is "an exogenous chemical substance or mixture that alters the function(s) of the endocrine system and thereby causes adverse effects to an organism, its progeny, or a (sub)population". In 2009, The Endocrine Society presented the Scientific Statement in which endocrine disruptor was defined as "a compound, either natural or synthetic, which through environmental or inappropriate developmental exposure alters the hormonal and homeostatic systems that enable the organism to communicate with and respond to its environment" (Diamanti-Kandarakis et al., 2009).

\section{Role of androgens and estrogens in male reproductive tract development and function}

Androgens are steroid hormones that play a central role in the development and function of male reproductive system (Dohle et al., 2003). The principal androgens are testosterone and dihydrotestosterone (DHT). High amounts of testosterone are produced in the testes from early stages of fetal development until birth. During prenatal period testosterone is necessary for the differentiation of Wolffian duct into the epididymis, vas deferens and seminal vesicles. It is also involved in the process of testis descent. DHT, synthesized from testosterone by the action of $5 a-$ reductase, mediates the masculinization of external genitalia and prostate. Studies by Welsh et al. (2008) revealed the existence of a fetal "masculinization programming window", a period within which androgens action is necessary to ensure correct later development of the male reproductive system. Blockade of androgen action 
only during this critical period by using androgen receptor antagonists (e.g., flutamide) suppresses development of the male accessory glands and disrupts testis descent leading to cryptorchidism (Macleod et al., 2010; Welsh et al., 2008). In rat masculinization programming window occurs at 15.5-18.5 gestational days, whereas in human it spans from approximately 8 to 14 weeks of gestation (Welsh et al., 2008). In neonates testosterone level is high for a short time, then its production decreases and is maintained at low level until puberty, when rising androgen level mediate growth and function of accessory sex glands, initiation of spermatogenesis and development of secondary male sex characteristics. In mature males androgen action is essential for the maintenance of male phenotype and fertility (Dohle et al., 2003).

The discovery that aromatase (the enzyme converting androgens to estrogens) and estrogen receptors $\alpha$ and $\beta$ (ER $\alpha$ and ER $\beta$ ) are expressed in male reproductive tract and studies on transgenic mouse models with inactivated estrogen receptor $\alpha(\alpha$ ERKO) or aromatase genes (ArKO) led to the conclusion that not only androgens, but also estrogens are important for development and physiology of male reproductive system (Bilinska et al., 1997; Carreau et al., 2003; Levallet et al., 1998; Lubahn et al., 1993; Kuiper et al., 1996; Robertson et al., 1999). It was demonstrated that during fetal and neonatal life estrogens are involved in control of gametogenesis, promoting germ cell and seminiferous tubule development, and in the regulation of fetal Leydig cell steroidogenesis (Albrecht et al., 2009; Delbés et al., 2005; Vigueras-Villaseñor et al, 2006). Aromatase and ERs are transiently expressed in the hippocampus of newborn males, suggesting that estrogens are involved in brain masculinization (McEwen \& Alves, 1999). In the reproductive system of adult males the role of ERs is associated with the maintenance of fluid reabsorption in the excurrent ducts of the testis (Hess, 2000; Hess et al., 1997). Data from studies on male mice with knockout of ERa suggested that long-term atrophy of the testes, observed in these animals, was caused by backpressure of the accumulating luminal fluids. Moreover, estrogens appear to have direct effects on the Leydig cell, controlling testosterone synthesis, and possibly on the seminiferous epithelium (Akingbemi et al., 2003; Hess, 2003). In male, estrogens play also a physiological role in non-reproductive tissues and organs such as bone and cardiovascular system (Oettel, 2002).

Although endogenous estrogens are necessary for normal male fertility, excessive production of these hormones or exposure to exogenous estrogens during fetal or neonatal life could produce adverse outcomes, affecting reproductive system development and adult reproductive functions. Destructive effects of estrogen overexposure on the development of post-meiotic germ cells and testicular atrophy was observed in rodents and humans (Gancarczyk et al., 2004; Toyama et al., 2001; Williams et al., 2001). Moreover, cryptorchidism, spermatogenic arrest, Leydig cell hyperplasia, and decreased serum folliclestimulating hormone (FSH) and testosterone levels have been reported in the transgenic mouse model with aromatase overexpression (Fowler et al., 2000; Li et. al., 2001).

\section{Antiandrogens}

Antiandrogens are defined as chemicals that interfere with androgen action or production. The compounds shown to have antiandrogenic properties include pharmaceuticals (e.g., flutamide, ketoconazole) as well as environmental contaminants: pesticides (e.g., vinclozolin, linuron) and industrial chemicals (e.g., di(n-butyl) phthalate). 


\subsection{Flutamide as a model antiandrogen}

Flutamide, a pharmaceutical used in therapy of androgen-dependent prostate cancer, and its active metabolite hydroxyflutamide, are non-steroidal synthetic androgen receptor (AR) antagonists, which display pure antiandrogenic activity, without exerting agonistic or any other hormonal activity (Neri, 1989; Singh et al., 2000). Flutamide is regarded as a model antiandrogen and in experimental studies it is often used as a positive control in screening assays used for the identification of endocrine disruptors (O'Connor et al., 1998).

In utero exposure to flutamide was shown to alter reproductive development and function in male rat offspring (Mikkila et al., 2006). Recently, it was reported that flutamide interferes with desert hedgehog (Dhh) signaling in the fetal testis, resulting in impaired fetal Leydig cell differentiation. Leydig cell dysfunction was reflected by suppressed levels of insulin-like factor 3 (Insl-3) and testosterone and reduced expression of steroidogenic enzymes,

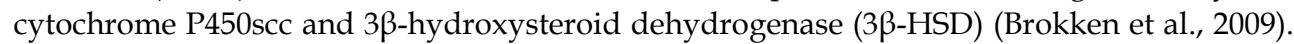
Insufficient levels of testosterone and Insl-3 in the fetal testis could, in turn, prevent full masculinization. Decrease in gonad and accessory sex glands weight, cryptorchidism, testicular histological lesions and increased germ cell apoptosis have been reported in adult male rats exposed to flutamide during fetal period, indicating that flutamide exerts longterm antiandrogenic effects (Omezzine et al., 2003).

In our recent studies flutamide $(50 \mathrm{mg} / \mathrm{kg} \mathrm{bw})$ was injected into pregnant gilts during gestational days $20-28$ and $80-88$, and into male piglets on postnatal days $2-10$. We found no changes in testicular morphology of neonatal pigs in utero exposed to flutamide, whereas in prepubertal males some of the seminiferous tubules were altered, exhibiting reduced number of Sertoli cells and dilated lumina (Durlej et al., 2011; Kopera et al., 2010). Testes of adult pigs exposed to flutamide in utero exhibited moderate alterations of the spermatogenic process: seminiferous tubules showed degeneration of germ cells and their extensive sloughing into the lumen of the seminiferous tubules, however all generations of germ cells could be recognized in the seminiferous epithelium. Testes of neonatally exposed boars contained severely altered seminiferous tubules, exhibiting drastic increase in the number of apoptotic germ cells, hypospermatogenesis or spermatogenic arrest at the spermatocyte level. Alterations of normal histological structure were accompanied by decreased expression and/or disturbed localization of intercellular junction proteins, connexin 43, N-cadherin, $\beta$-catenin and ZO-1 in the seminiferous epithelium (Hejmej et al., 2011a; Kopera et al., 2011). Also interstitial tissue was adversely affected; Leydig cells displayed hyperplasia or hypertrophy, increased expression of aromatase and reduced expression of LH receptor. Dysfunction of Leydig cells led to disruption of androgenestrogen balance (Kotula-Balak et al., submitted for publication). These data suggest that in pigs flutamide acting during fetal, and especially, neonatal period can reprogram the development of testicular cells, leading to morphological and functional alterations of the testis at adulthood.

Interestingly, flutamide exposure has also long-term effects on sperm morphology. Our data showed that in sperm derived from neonatally-treated boars either flattened head or abnormal sperm with altered shape of the acrosome and abnormal packaging of sperm chromatin were frequently observed. Prepuberal treatment with flutamide resulted in an increased number of sperm displaying abnormal midpiece or tail defects (Lydka et al., submitted for publication) 
Several studies demonstrated the effects of short-term androgen blockage induced by the administration of flutamide to immature or mature males. In immature rats structure of interstitial tissue and seminiferous epithelium, and the expressions of steroidogenesisrelated genes, Cyp11a1 and StAR, were significantly affected by flutamide treatment (Vo et al., 2009). When administered to pubertal animals, flutamide accelerated testes maturation, causing degeneration and detachment of primary spermatocytes and round spermatids (Maschio et al., 2010). In adult males, germ-cell degeneration, alterations in ectoplasmic specialization between the Sertoli cell and spermatids, and premature detachment of spermatids, as well as increase in the relative volume of Leydig cells were observed (Anahara et al., 2008; Maschio et al., 2008). Moreover, our in vitro results showed that pig sperm incubated with hydroxyflutamide $(50$ and $100 \mu \mathrm{g} / \mathrm{mL})$ displayed disorders in sperm phospholipid membrane, decreased oxidative capability of sperm mitochondria and decreased sperm membrane integrity (Lydka et al., submitted for publication)

\subsection{Environmental antiandrogens}

\subsubsection{Pesticides: procymidone, vinclozolin, prochloraz, linuron and p,p'DDE}

Procymidone is used as a fungicide for the control of plant diseases. High quantities of this compound were found in rice, tomatoes and grapes (Gebara et al., 2011; US Environmental Protection Agency annual report, 1994). When administered to pregnant rats, the male pups displayed a reduced anogenital distance, nipple retention, hypospadias, cleft phallus, and reduced sex accessory gland size (Gray et al., 1999; Ostby et al., 1999). Moreover, in prostate and seminal vesicles fibrosis, cellular infiltration and epithelial hyperplasia were observed (Ostby et al., 1999). Chronic treatment of male rats with procymidone inhibited the negative feedback exerted by androgens on the hypothalamus and/or the pituitary, causing enhanced luteinizing hormone (LH) secretion and Leydig cell steroidogenesis, and in consequence, increased serum testosterone level (Hosokawa et al., 1993; Svechnikov et al., 2005). Such a long-term hyperstimulation of Leydig cells induces Leydig cell tumors (Murakami et al., 1995).

Vinclozolin is a dicarboximide fungicide used in the control of Botrytis cinerea, Sclerotinia sclerotiorum, and Moniliniam spp on vegetables, fruits and ornamental plants. Vinclozolin and its two active metabolites, M1 and M2, compete for androgen binding to AR and inhibit AR transactivation and androgen-dependent gene expression (Wong et al., 1995). Administration of vinclozolin to pregnant rats resulted in abnormalities of androgenregulated sexual differentiation in male offspring, including reduced anogenital distance, nipple retention, hypospadias, cryptorchidism, decreased sex accessory gland growth as well as in induction of prostate inflammation and reduced sperm production at adulthood (Cowin et al., 2010; Gray et al. 1994; 1999). Vinclozolin has also been implicated in epigenetic modifications of male reproductive tract via changes in DNA methyltransferase expression (Anway et al., 2008; Anway \& Skinner, 2008). The most sensitive period of rat fetal development to the effects of vinclozolin was found to be gestational days 16-17, whereas less severe malformations were seen in males exposed during gestational days 14-15 and 18-19 (Wolf et al. 2000). Peripubertal exposure resulted in delayed pubertal maturation, decreased sex accessory gland and epididymal growth concomitantly with increased serum levels of LH and testosterone (Monosson et al., 1999).

Prochloraz is an imidazole fungicide widely used in gardening and agriculture which acts as both AR antagonist and inhibitor of fetal testosterone production. In addition to 
antiandrogenic action, prochloraz antagonizes the estrogen receptor, agonizes the aryl hydrocarbon (Ah) receptor and suppresses aromatase activity (Andersen et al., 2002; Vinggaard et al., 2006). Gestational exposure significantly reduces testosterone production by inhibiting activity of cytochrome P450c17, decreases reproductive organ weights, increases nipple retention and induces malformations (e.g., hypospadias) in androgendependent tissues of male offspring (Blystone et al. 2007; Laier et al., 2006; Noriega et al., 2005; Vinggaard et al., 2005).

Linuron is a herbicide employed to control of weeds in crops and potatoes (Gray et al., 2006). It binds $A R$ and inhibits dihydrotestosterone induced gene expression in vitro (Lambright et al., 2000). Fetal exposure to linuron resulted in epididymal and testicular abnormalities, reduced anogenital distance and nipple retention; however, in contrast to other AR antagonists, it does not induce hypospadias and cryptorchidism. Moreover, linuron was shown to decrease testosterone production by fetal Leydig cells (McIntyre et al., 2000, 2002a, 2002b; Wilson et al., 2009). Thus its mechanism of action resembles those of phthalates (Gray et al., 2006). Interestingly, when administered to sexually immature and mature rats, linuron decreased weights of accessory sex organs, increased serum estradiol and LH levels, and produced Leydig cell tumors (Cook et al., 1993).

$\mathrm{p}, \mathrm{p}^{\prime}$-DDE (dichlorodiphenyldichloroethylene) is a metabolite of the persistent pesticide, DDT (dichlorodiphenyltrichloroethane). DTT is now banned in most countries, since in 1960 ' it was discovered that it has endocrine disrupting properties and causes birth defects in human and animals. However, it is still used in some regions to prevent malaria and other tropical diseases spread by insects (van den Berg et al., 2009). p,p'-DDE acts as AR antagonist both in vivo and in vitro (Kelce et al., 1995). Fetal treatment with this compound was shown to affect male development, leading to reduced anogenital distance, nipple retention and hypospadias (You et al., 1998). Recently, it was reported that p, $\mathrm{p}^{\prime}$-DDE induces testicular apoptosis in pubertal rats through the involvement of Fas/FasL, mitochondria and endoplasmic reticulum-mediated pathways (Shi et al., 2011).

\subsubsection{Phthalates}

The diesters of 1,2-benzenedicarboxylic acid, called phthalates, are widely used as plasticizers in the production of toys, medical devices, rainwear, food packaging, and certain cosmetics (Schettler, 2006). Di-n-butyl phthalate (DBP) and di(2-ethylhexyl) phthalate (DEHP) and their metabolites have been shown to cause antiandrogenic effects, however, without binding to AR (Frederiksen et al., 2007). Although, the exact mechanism of action is not yet fully elucidated, it was demonstrated that phthalates interfere with Leydig cell function, reducing the expression of most of genes involved in testosterone biosynthesis (Barlow et al., 2003). Fetal exposure to phthalates results in reduced anogenital distance, hypospadias, cryptorchidism, malformed epididymis, and nipple retention (Mylchreest et al., 1999, 2002; Mylchreest \& Foster, 2000). At the histological level, multinucleated gonocytes, detachment of gonocytes from the seminiferous epithelium, Sertoli cell-only tubules and Leydig cell hyperplasia were found in the testes of males exposed to DEHP and DBP (Fisher et al., 2003; Mylchreest et al., 2002; Parks et al., 2000). Some of these alterations were permanent and affected testicular function in adulthood, resulting in low testosterone level and reduced sperm count. It is worth noting that histological changes induced in rat by in utero exposure to phthalates resemble those observed in patients with TDS (Fisher, 2004a). 


\section{Xenoestrogens}

Compounds with estrogenic activity, called xenoestrogens, comprise a broad range of synthetic chemicals (e.g., diethylstilbestrol, bisphenol-A, octylphenol, nonylphenol), naturally occurring phytoestrogens (e.g., genistein, resveratrol) and heavy metals (e.g., cadmium, lead, and boron).

\subsection{Diethylstilbestrol (DES)}

DES is synthetic potent non-steroidal estrogen used as a supplement in cattle and poultry feed and as a pharmaceutical (Rubin, 2007). DES was given to pregnant women to prevent miscarriages or premature deliveries from about 1940 to 1970. It was restricted in 1971 because of increased risk of a rare reproductive tract cancer, vaginal clear cell adenocarcinoma, in daughters of women who had taken DES (Gill et al., 1979; Melnick et al., 1987). Further studies have reported multiple adverse effects in males and females as a result of prenatal DES exposure. In males decreased fertility and anatomical malformations of reproductive organs such as cryptorchidism, epididymal cysts and prostatic squamous metaplasia were observed (Driscoll \& Taylor, 1980; Marselos \& Tomatis, 1992; Mittendorf, 1995).

Nowadays, experimental animals exposed to DES during fetal and neonatal development are useful models for studying mechanisms of endocrine disruption caused by exogenous estrogenic compounds (Diamanti-Kandarakis et al., 2009). In male mice exposed to DES during gestation, cryptorchidism, hypospadias, as well as underdeveloped epididymis, vas deferens and seminal vesicles were observed (McLachlan et al., 2001). Similarly, neonatal treatment of male rats with DES induced a wide range of reproductive abnormalities, including delay of testicular descent, retardation of pubertal spermatogenesis, reduction in testis weight, infertility, and gross morphological alterations in the rete testis, efferent ducts, epididymis and accessory sex glands (Atanassova et al., 1999, 2000; Fisher et al., 1999; McKinnell et al, 2001; Williams et al., 2001). Testes of adult rats neonatally exposed to DES displayed suppression of Leydig cell development and steroidogenesis, reduced Sertoli cell proliferation and spermatogenic impairment. It was shown that DES has both direct and pituitary-mediated effects on the developing testis, leading to decreased expression of AR and reduced FSH level (Sharpe et al., 1998, 2003). Studies on transgenic mouse models with inactivated ERs suggest that DES elicits its toxic effects in the male reproductive tract through an ERa-mediated mechanism (Prins et al., 2001).

\subsection{Environmental xenoestrogens}

\subsubsection{Industrial xenoestrogens: bisphenol $A$ and alkylphenols}

Bisphenol A (BPA) is one of the most important industrial chemicals, which worldwide production is over 500000 tons per year. It is found mainly in plastic food containers, baby bottles, the resins lining food cans, dental sealants, cardboards, and as an additive in other plastics (Richter et al., 2007). BPA is structurally similar to DES and can act by binding to ERa and ER $\beta$, and through other mechanisms, since some effects differ from those observed in response to activation of estrogen receptors. In vivo and in vitro experiments revealed that BPA mimics estrogen action, however it is also able to antagonize the activity of estradiol, acting as a selective estrogen receptor modulator (SERM) (Welshons et al., 2006). In high concentrations BPA can bind to AR and inhibit the androgen action (Lee et al., 2003). Although BPA is approximately 1000- to 2000-fold less potent than estradiol, exposure to 
environmentally relevant doses impacts the reproductive system development and function in male rodents (Richter et al., 2007). It was demonstrated that rodents exposed to BPA during fetal and/or neonatal life had decreased weights of the epididymis and seminal vesicles, but increased weights of the prostate and preputial glands, decreased epithelial height in the efferent ducts and decreased levels of testicular testosterone (Akingbemi et al., 2004; Fisher et al., 1999; vom Saal et al., 1998). Alterations in ectoplasmic specialization between the Sertoli cell and spermatids, abnormalities in the acrosomal granule and nucleus of spermatids, reduced percentage of motile sperm, and increased incidence of sperm malformations were also observed (Aikawa et al., 2004; Toyama et al., 2004). Similar changes in the seminiferous epithelium and reduced fertility were found in adult males treated with BPA (Toyama et al., 2004). BPA was found to act directly on Leydig cell steroidogenesis, affecting the expression of cytochrome cytochrome P450 17a-hydroxylase/ $\mathrm{C}_{17-20}$ lyase (P450c17) and aromatase enzymes and interfering with $\mathrm{LH}$ receptor-ligand binding (Akingbemi et al., 2004; Svechnikov et al., 2010).

Alkylphenols, such as 4-nonylphenol and 4-tert-octylphenol, are used to manufacture the alkylphenol polyethoxylates, non-ionic surfactants used as detergents, plasticizers, emulsifiers and modifiers in paints, pesticides, textiles, and personal care products. Alkylphenols present in the environment, mainly in wastewater and rivers, derive from the release of unreacted alkylphenols during manufacturing as well as from degradation of the alkylphenol polyethoxylates in the environment (Blake et al., 2004; Staples et al., 2001). Currently, alkylphenols have been found in human urine and breast milk (Ademollo et al., 2008; Calafat et al., 2008,). Octylphenol and nonylphenol has been reported to exhibit weak estrogenic activity as demonstrated by its ability to bind and activate the estrogen receptors (Kuiper et al., 1998; Lee, 1998; Safe et al., 2000). Although these chemicals are between 100 and 10000-fold less estrogenic than $17 \beta$-estradiol, the widespread use of these compounds causes that they largely contribute to the environmental estrogen pool (Blake \& Bookfor, 1997).

Maternal exposure to octylphenol was shown to affect the expression of genes essential for reproductive system development, such as steroidogenic factor-1 (SF-1) and steroidogenic enzymes in rat testes (Majdic et al., 1996, 1997). In the lamb, it was demonstrated to inhibit the secretion of FSH in the fetus with a concomitant decrease in testis size and Sertoli cell number at birth (Sweeney et al., 2000). In adult males exposed in utero or neonatally to alkylphenols abnormalities in reproductive organs histology, reduced weight of the testis, epididymis and prostate, reduced testosterone level as well as increased number of abnormal sperm and decreased sperm production were observed (Aydoğan \& Barlas, 2006; Jie et al., 2010; Lee, 1998; Yoshida et al., 2001). These alterations may result from both modulation of the hypothalamus-pituitary axis and direct estrogenic action in reproductive tissues (Yoshida et al., 2001). Importantly, all these effects were observed only when relatively high doses $(400 \mathrm{mg} / \mathrm{kg}$ bw) of alkylphenols were used (Atanassova et al., 2000; Sharpe et al., 2003).

Administration of high doses of alkylphenols to adult males resulted in reduced size and function of the testis, epididymis and male accessory glands, decreased serum LH, FSH and testosterone concentrations, increased apoptosis of germ cells and reduced sperm count (Blake \& Boockfor, 1997; Boockfor \& Blake, 1997; Han et al., 2004; Gong \& Han, 2006; Kim et al., 2007). However, reports on the effects of lower doses ( $<200 \mathrm{mg} / \mathrm{kg} \mathrm{bw})$ of octylphenol on male reproductive system are contradictory (Bian et al., 2006; Kim et al., 2007). 
Recently, bank vole, a seasonally breeding rodent, was used to investigate the effects of 4tert-octylphenol on testes and seminal vesicles, depending on the length of exposure and reproductive status of animals. Adult bank vole males kept under long or short photoperiod were orally administered octylphenol $(200 \mathrm{mg} / \mathrm{kg} \mathrm{bw})$ for 30 or 60 days. We found that treatment for 30 days had no effect on the reproductive organs, whereas treatment for 60 days adversely influenced sperm morphology as well as weights and histological structure of the testes and seminal vesicles. In these tissues, expression of $3 \beta-\mathrm{HSD}$ and AR, and testosterone levels were decreased, concomitantly with increased expression of aromatase and ERa, and elevated estradiol levels, resulting in androgen-estrogen imbalance. These data indicate that long-term exposure to octylphenol is necessary to affect male reproductive organs histology and hormonal milieu. Furthermore, a subtle difference in the sensitivity to octylphenol between voles kept in different light conditions was noted (Hejmej et al., 2011b). In a further study negative effects of this compound on MA-10 Leydig cells in vitro have been reported. In cell cultures treated with different octylphenol concentrations, doserelated changes in the cytoarchitecture of MA-10 cells, including cytoplasm vacuolization and altered size and distribution of lipid droplets, were visible. Moreover, it was shown that high doses attenuate $3 \beta$-HSD and AR expression, concomitantly with the reduction of progesterone synthesis. Based on this results it was hypothesized that octylphenol besides binding to ERs may use other potential routes of action such as effects on the AR (KotulaBalak et al., 2011).

\subsubsection{Phytoestrogens}

Phytoestrogens are plant compounds, structurally similar to $17 \beta$-estradiol and thus exhibiting estrogenic or antiestrogenic activity. There are four main classes of phytoestrogens: isoflavones (genistein, daidzein, biochanin A, naringenin), coumestans (coumestrol), lignans (matairesinol) and stilbene (resveratrol). Phytoestrogens are present in fruits, vegetables and leguminous plants, but the main source of these compounds in human diet are soy-based products, i. a. soy-based infant formula, that contain high concentration of genistein and daidzein (Reinli \& Block, 1996; Setchell et al., 1997). It is believed that isoflavones exert beneficial effects in prevention of cancer, cardiovascular diseases and osteoporosis, however it was reported that they can adversely affect development and function of male and female reproductive function (Lee et al., 2004; Suthar et al., 2001). This may be of special concern in case of infants fed with soy formula milk. Although, phytoestrogens binding affinity to the estrogen receptors is 1000-10000-fold lower compared with the $17 \beta$-estradiol, in infants, which consume even $9 \mathrm{mg} / \mathrm{kg} /$ day of isoflavones, mainly genistein, blood concentrations of the isoflavones exceed 1000 times those of endogenous estradiol and are higher than the amount reported to produce hormonal effects in adult women (Henley \& Korach et al., 2010; Schmitt et al., 2001; Setchell et al., 1997). Therefore in recent years multiple studies on animal models were undertaken to elucidate the mechanism of action and the consequences of exposure to genistein. In rodents dietary administration of genistein induced Leydig cell hyperplasia and decrease of testosterone level by down-regulation of the expression of steroidogenic enzymes (e.g., cytochrome P450scc) (Svechnikov et al., 2005). In vivo and in vitro data indicate that genistein is able to signal through both ERa and ER $\beta$, depending on the specific tissue (Mueller et al., 2004).

In recent years resveratrol, a stilbene found in grapes and wine, has been widely used to prevent cardiovascular diseases, since it was shown to inhibit oxidation of LDL cholesterol, 
platelets aggregation and synthesis of eikozanoids (Kris-Etherton et al., 2002). However, resveratrol appeared to have adverse effect on Leydig cell steroidogenesis through suppression of the expression of StAR and cytochrome P450c17 (Svechnikov et al., 2009).

Estrogenic activity is also attributed to several other compounds derived from plants, for example lavender oil and tea tree oil, frequently used in cosmetics, such as lotions, gels, and creams. It is supposed that exposure to these chemicals may induce prepubertal gynecomastia in humans. In vitro experiments revealed that apart from estrogenic activity both lavender and tea tree oil possess antiandrogenic properties (Henley et al., 2007; Henley \& Korach et al., 2010).

Interestingly, based on the analysis of published data concerning correlations between exposure to different endocrine disruptors and decrease in sperm counts and increase in testicular cancer rate, Safe (2004) suggested that dietary phytoestrogens, rather than synthetic environmental endocrine disruptors may by involved in induction of reproductive tract disorders in human.

\subsubsection{Methoxychlor}

Methoxychlor was introduced in 1944 to substitute more persistent and more toxic insecticide, DDT. It is used on agricultural crops, livestock, animal feed, grain storage, home gardens, and on pets. Methoxychlor exhibits mixed estrogenic and antiandrogenic activity: the most active estrogenic metabolite is HPTE [2,2-bis-( $p$-hydroxyphenyl)-1, 1, 1trichloroethane], whereas other metabolites have antiandrogenic activity (Cummings, 1997; Dehal \& Kupfer, 1994; Kelce \& Wilson, 1997). HPTE has differential effects on ERs, being an ERa agonist and ER $\beta$ antagonist (Gaido et al., 1999, 2000). In cultured Leydig cells from immature and adult rats, HPTE was shown to inhibit both basal and hCG-stimulated testosterone production, and these effects were reported to be mediated through the ER (Murono \& Derk, 2005). Recently, a direct inhibitory activity of methoxychlor and HPTE on $3 \beta$-HSD and 17 $\beta$-hydroxysteroid dehydrogenase (17 $\beta$-HSD) was reported (Hu et al., 2011). Exposure to methoxychlor during gestation or neonatal period affected embryonic testis cellular composition, Sertoli and germ cell numbers, germ cell survival and epididymal sperm count, reducing spermatogenic potential of males (Chapin et al., 1997; Johnson et al., 2002; Suzuki et al., 2004). In adult rat testis methoxychlor induced apoptosis via mitochondria- and FasL-mediated pathways (Vaithinathan et al., 2010).

\subsubsection{Heavy metals}

Numerous heavy metals (e.g., cadmium, lead, arsenic, boron, mercury, antimony, aluminum, cobalt, chromium, lithium) have been demonstrated to adversely affect the reproductive function of human and experimental animals. For example, cadmium, used in battery electrode production, galvanizing, plastics, alloys and paint pigments, has potent estrogen- and androgen-like activities in vivo and in vitro (Sikka et al., 2008; Takiguchi \& Yoshihara, 2006). In mice exposed to cadmium during late gestation and puberty markedly reduced weights of testes, epididymides, prostate and seminal vesicles, and decreased testosterone levels were observed. Moreover, testicular expression of StAR and steroidogenic enzymes, such as cytochrome P450scc, 17a-HSD and 17 $\beta$-HSD, was downregulated (Ji et al., 2010, 2011). In the seminiferous tubules, cadmium caused disruption of the blood-testis barrier and oxidative stress, leading to germ cell degeneration, seminiferous tubules vacuolization, and aberrant morphology and apoptosis of Sertoli cells (de Souza 
Predes et al., 2010; Zhang et al., 2010). Epidemiological and animal studies have additionally demonstrated a carcinogenic effect of cadmium on the prostate (Nakamura et al., 2002).

Lead, another metal widespread in the environment, has adverse reproductive effect on the testes and the hypothalamic-pituitary axis. In animal studies, lead has been shown to reduce serum testosterone and FSH levels, disrupt spermatogenesis and induce oxidative cellular damage in epididymis (Foster at al., 1998; Marchlewicz et al., 2004; Sokol et al., 1985). Clinical studies have associated exposure to lead with reduced libido, reduced sperm motility and sperm count, chromosomal damage, infertility, and changes in serum testosterone (Braunstein et al., 1978; Winder, 1989).

\section{Mechanisms of action}

Endocrine disruptors affect cellular processes by different modes of action. They can act by mimicking the action of naturally produced hormones, blocking their receptors in target cells or altering the synthesis or metabolism of hormones and hormone receptors. It is important to note, that many endocrine disruptors have more than one mechanism of action (e.g., methoxychlor) (Gaido et al., 2000). Some can be metabolized to hormonally active compounds, exhibiting different properties (e.g., DDT and its metabolite DDE) (Kelce et al., 1995). Moreover, even compounds with the same supposed mechanism of action can induce different effects after exposure. It was also demonstrated that action of some xenoestrogens may be different in various tissues; thus they can act as SERMs (e.g., BPA, resveratrol, naringenin) (Gehm et al., 1997; Gould et al., 1998; Yoon et al., 2001).

\subsection{Interaction with hormone receptors}

Endocrine disruptors can bind to specific hormone receptors and act via agonistic or antagonistic mechanism. Numerous xenoestrogens (e.g., BPA, alkylphenols, genistein) activate estrogen receptors, interacting with their binding pockets (Lehraiki et al., 2011; Mueller, 2004; Singleton \& Khan, 2003). It is possible due to structural similarities of these compounds to estradiol. The affinity of xenoestrogens to the estrogen receptor and/or their ability to initiate nuclear retention and transcriptional effects is usually lower than those of estradiol. It is worth noting, however, that weak activity via receptor-dependent pathway does not necessarily predict the potency of the chemical acting via another signaling pathway. Moreover, many xenoestrogenic compounds bioaccumulate in fat tissues, resulting in prolonged exposure (Watson et al., 2011). Several estrogenic chemicals, among others flavonoids and resveratrol, have been shown to interact not only with ERs, but also with aryl hydrocarbon receptor (AhR) (Revel et al., 2003; Van der Heiden, et al., 2009).

Antiandrogens, such as flutamide, vinclozolin, prochloraz and linuron, repress ARmediated transcriptional activation, by competitive inhibition of endogenous androgens binding to their receptor (Gray et al., 1999; Lambright et al., 2000; Mohler et al., 2009; Noriega et al., 2005; Vinggaard et al., 2002). Binding of antiandrogen may result in a conformational change of ligand binding domain of AR appropriate for the interaction with co-repressors, instead of coactivators (Berrevoets et al., 2002; Hodgson et al., 2008).

Besides classical intracellular steroid hormone receptors, several membrane steroid receptors, capable to mediating non-genomic steroid actions, have been described (Thomas \& Dong, 2006; Watson et al., 2007). BPA has been shown to bind to membrane-bound form of ERa (mER) and a transmembrane G protein-coupled receptor 30 (GPR30) (Watson et al., 2005). This GPCR-mediated non-genomic action included activation of cAMP-dependent 
protein kinase and cGMP-dependent protein kinase pathways and a rapid phosphorylation of the transcription factor cAMP response-element-binding protein (CREB) (Bouskine et al., 2009). Recent results revealed the possibility that BPA may have adverse effects on spermatogenesis via activation of extracellular signal-related kinases 1 and 2 (ERK1/2) (Izumi et al., 2011). Also alkylphenols and phytoestrogens appear to activate non-genomic pathways, signaling via calcium influx and activation of mitogen-activated protein kinases (MAP kinases) (Bulayeva \& Watson, 2004; Wozniak et al., 2005).

\subsection{Alterations in synthesis, metabolism and transport of hormones or their receptors} It was reported that some endocrine disruptors can interfere with steroid synthesis or metabolism, acting via non-receptor mediated mechanisms (Fisher, 2004b). Phthalates induce antiandrogenic effects, however they do not interact with the AR (Lehraiki et al., 2009; Stroheker et al., 2005,). It was demonstrated that DBP and DEHP decrease fetal testosterone synthesis by reducing the expression of steroidogenic genes, such as Cyp17, Cyp11a and StAR (Barlow \& Foster, 2003; Borch et al., 2006; Howdeshell et al., 2007; Parks et al., 2000). Phthalates were also shown to decrease the expression of Insl-3, a factor produced by fetal Leydig cells. Insl-3 is an important regulator of testicular descent and phthalateinduced reduction of Insl-3 is consistent with the high incidence of cryptorchidism (Gray et al., 2006; Laguë \& Tremblay, 2008; Wilson et al., 2004). In contrast to phthalates, in utero exposure to prochloraz decreases testosterone production by direct inhibition of the activity of steroidogenic enzymes without affecting the mRNA expression of these enzymes (Blystone et al., 2007; Wilson et al., 2008).

As mentioned above, biosynthesis of estrogens is catalyzed by the enzyme aromatase. Various endocrine disruptors were reported to alter the expression or activity of aromatase, leading to testosterone-estradiol imbalance. Enhanced expression of aromatase was found in testes of males exposed to octylphenol and BPA (Hejmej et al., 2011b; Kim et al., 2010), whereas prochloraz reduced aromatase expression (Vinggaard et al., 2006). Estradiol level can also be influenced by inhibition of SULT 1A1 and 2E1 enzymes, which catalyze inactivation of estrogens by sulphation. It was shown that alkylphenols and phthalates, suppressing these enzymes, cause a rise in the levels of the free active endogenous estrogens (Waring \& Harris, 2005).

Some endocrine disruptors may additionally influence the expression levels of hormone receptors, shifting the balance between concentrations of endogenous ligand and its receptor. For instance, it was reported that exposure to DES (McKinnell et al., 2001; Williams et al., 2001) and octylphenol (Hejmej et al., 2011b; Kotula-Balak et al., 2011) results in upregulation of ERa and down-regulation of $\mathrm{AR}$ in male reproductive tissues.

In case of steroid hormones, the level of bioavailable hormone is determined not only by the level of synthesis and metabolism, but also by concentration of steroid hormone-binding globulin (SHBG), protein involved in transport of steroids in the blood. Studies revealed that endocrine disruptors may influence SHBG level, altering the level of free, bioavailable hormone (Bagchi et al., 2009; Sikka \& Wang, 2008).

It should be mentioned, that xenoestrogens and antiandrogens affect reproductive functions not only acing directly on reproductive organs, but also disturbing hypothalamus-pituitarytesticular axis. For example, in adult male rats exposed to BPA during pre- and early postnatal periods, LH serum levels showed no changes, whereas FSH and testosterone levels decreased significantly (Cardoso et al., 2011). Secretion of FSH was also reduced following prenatal octylphenol and vinclozolin exposure (Sweeney et al., 2000; Veeramachaneni et al., 2006b). 


\subsection{Epigenetic mechanisms}

Epigenetic modifications are regulators in numerous biological processes, including spermatogenesis. Key mechanism in establishing epigenetic change is DNA methylation, which usually suppresses expression of the gene. Several studies revealed that endocrine disrupting chemicals are implicated in epigenetic programming and DNA methylation (McLachlan, 2001; Skinner \& Anway, 2005). Indeed, hypermethylation found in several genes in the sperm DNA (i. a. Mest, Snrpn, Peg1 and Peg3) was accompanied by the reduction of semen quality (Stouder \& Paoloni-Giacobino, 2010). These changes may be heritable, if they occur during certain stages of development (Crews \& McLachlan, 2006). It was demonstrated that methoxychlor and vinclozolin when administered during prenatal period interfere with testis development and lead to increased spermatogenic cell apoptosis and decreased fertility in the adult males. These spermatogenic defects were also evident in subsequent generations (Chang et al., 2006; Skinner \& Anway, 2005). Also maternal exposure to BPA resulted in postnatal changes in DNA methylation status and altered expression of specific genes in offspring (Bernal \& Jirtle, 2010; Kundakovic \& Champagne, 2011).

Taken together, estrogenic and antiandrogenic compounds act by multiple mechanisms of toxicity disrupting the interactions among the interconnected signaling pathways in reproductive tissues. Importantly, in the environment organisms are usually exposed to mixtures of multiple endocrine disruptors, which can produce cumulative effects, regardless of the mode of action of the individual mixture component (Gray et al., 2006).

\section{Conclusion}

Experimental studies clearly suggest that estrogenic and antiandrogenic compounds could cause alterations of sexual differentiation and impairment of male reproductive functions. Although the process of spermatogenesis is directly vulnerable to exposure to endocrine disrupting agents only in sexually mature males, above-mentioned data imply that exposure during the period of reproductive system development may have subsequent impact on the reproductive functions in adulthood. Fetal and neonatal exposures might result in the reprogramming of the developmental process of testicular cells, leading to their irreversible dysfunction. In contrast, adverse effects on the process of spermatogenesis in adulthood can be reversible (Sharpe, 2010; West et al., 2005). It is likely, therefore, that fetal and neonatal periods are of critical importance, when considering the role of hormonally active chemicals in male reproductive functions.

\section{Acknowledgment}

This work was financially supported by the Foundation for Polish Science, an Academic Grant 2008 (Mistrz Programme) and by the Ministry of Science and Higher Education, Grant N N303816640.

\section{References}

Acerini, C. L.; Miles, H. L.; Dunger, D. B.; Ong, K. K. \& Hughes, I. A. (2009) The descriptive epidemiology of congenital and acquired cryptorchidism in a UK infant cohort Archives of Disease in Childhood, Vol.94, No.11, (November 2009), pp. 868-872, ISSN 0003-9888 
Ademollo, N.; Ferrara, F.; Delise, M, Fabietti, F. \& Funari, E. (2008) Nonylphenol and octylphenol in human breast milk. Environment International, Vol.34, No.7, (October 2008), pp. 984-987, ISSN 0160-4120

Aikawa, H.; Koyama, S.; Matsuda, M.; Nakahashi, K.; Akazome, Y. \& Mori, T. (2004) Relief effect of vitamin A on the decreased motility of sperm and the increased incidence of malformed sperm in mice exposed neonatally to bisphenol A. Cell and Tissue Research, Vol.315, No.1, (January 2004), pp. 119-124, ISSN 0302-766X

Akingbemi, B. T.; Ge, R.; Rosenfeld, C. S.; Newton, L. G.; Hardy, D. O.; Catterall, J. F.; Lubahn, D. B.; Korach, K. S. \& Hardy, M. P. (2003) Estrogen receptor-alpha gene deficiency enhances androgen biosynthesis in the mouse Leydig cell. Endocrinology, Vol.144, No.1, (January 2003), pp. 84-93, ISSN 0013-7227

Akingbemi, B. T.; Sottas, C. M.; Koulova, A. I.; Klinefelter, G. R. \& Hardy, M. P. (2004) Inhibition of testicular steroidogenesis by the xenoestrogen bisphenol $\mathrm{A}$ is associated with reduced pituitary luteinizing hormone secretion and decreased steroidogenic enzyme gene expression in rat Leydig cells. Endocrinology, Vol.145, No.2, (February 2004), pp. 592-603, ISSN 0013-7227

Albrecht, E. D.;, Lane, M. V.; Marshall, G. R.; Merchenthaler, I.; Simorangkir, D. R.; Pohl, C. R.; Plant, T.M. \& Pepe, G. J. (2009) Estrogen promotes germ cell and seminiferous tubule development in the baboon fetal testis. Biology of Reproduction, Vol.81, No.2, (August 2009), pp. 406-414, ISSN 0368-2315

Anahara, R.; Toyama, Y. \& Mori, C. (2008) Review of the histological effects of the antiandrogen, flutamide, on mouse testis. Reproductive Toxicology, Vol.25, No.2, (February 2008), pp. 139-143, ISSN 0890-6238

Andersen, H. R.; Vinggaard, A. M.; Rasmussen, T. H.; Gjermandsen, I.M. \& BonefeldJørgensen, E. C. (2002) Effects of currently used pesticides in assays for estrogenicity, androgenicity, and aromatase activity in vitro. Toxicology and Applied Pharmacology, Vol.179, No.1, (February 2002), pp. 1-12, ISSN 0041-008X

Andersson, A.M.; Jørgensen, N.; Main, K.M.; Toppari, J.; Rajpert-De Meyts, E.; Leffers, H.; Juul, A.; Jensen, T.K. \& Skakkebaek, N.E. (2008) Adverse trends in male reproductive health: we may have reached a crucial 'tipping point'. International Journal of Andrology, Vol.31, No.2, (April 2008), pp. 74-80, ISSN 0105-6263

Anway, M. D. \& Skinner, M. K. (2008) Epigenetic programming of the germ line: effects of endocrine disruptors on the development of transgenerational disease. Reproductive Biomedicine Online, Vol.16, No.1, (January 2008), pp. 23-25, ISSN 1472-6483

Anway, M. D.; Rekow, S. S. \& Skinner, M. K. (2008) Comparative anti-androgenic actions of vinclozolin and flutamide on transgenerational adult onset disease and spermatogenesis. Reproductive Toxicology, Vol.26, No.2, (October 2008), pp. 100-106, ISSN 0890-6238

Atanassova, N.; McKinnell, C.; Turner, K. J.; Walker, M.; Fisher, J. S.; Morley, M.; Millar, M. R.; Groome, N. P. \& Sharpe, R. M. (2000) Comparative effects of neonatal exposure of male rats to potent and weak (environmental) estrogens on spermatogenesis at puberty and the relationship to adult testis size and fertility: evidence for stimulatory effects of low estrogen levels. Endocrinology, Vol.141, No.10, (October 2000), pp. 3898-38907, ISSN 0013-7227

Atanassova, N.; McKinnell, C.; Walker, M.; Turner, K. J.; Fisher, J. S.; Morley, M.; Millar, M. R.; Groome, N. P. \& Sharpe, R. M. (1999) Permanent effects of neonatal estrogen 
exposure in rats on reproductive hormone levels, Sertoli cell number, and the efficiency of spermatogenesis in adulthood. Endocrinology, Vol.140, No.11, (November 1999), pp. 5364-5373, ISSN 1477-7827

Auger, J.; Kunstmann, J. M.; Czyglik, F. \& Jouannet, P. (1995). Decline in semen quality among fertile men in Paris during the past 20 years. The New England Journal of Medicine, Vol.332, No.5, (February 1995), pp. 281-285, ISSN 0028-4793

Aydoğan, M. \& Barlas, N. (2006) Effects of maternal 4-tert-octylphenol exposure on the reproductive tract of male rats at adulthood. Reproductive Toxicology, Vol.22, No.3, (October 2006),pp. 455-460, ISSN 0890-6238

Bagchi, G.; Hurst, C. H. \& Waxman, D. J. (2009) Interactions of methoxyacetic acid with androgen receptor. Toxicology and Applied Pharmacology, Vol.238, No.2, (July 2009), pp. 101-110, ISSN 0041-008X

Barlow, N. J.; Phillips, S. L.; Wallace, D. G.; Sar, M.; Gaido, K. W. \& Foster, P. M. (2003) Quantitative changes in gene expression in fetal rat testes following exposure to di(n-butyl) phthalate. Toxicological Sciences, Vol.73, No.2, (June 2003), pp. 431-441, ISSN 1096-6080

Barlow, N.J. \& Foster, P. M. (2003) Pathogenesis of male reproductive tract lesions from gestation through adulthood following in utero exposure to di(n-butyl) phthalate. Toxicologic Pathology, Vol.31, No.4, (July-August 2003), pp. 397-410, ISSN 0940-2993

Barnhoorn, I. E.; Bornman, M. S.; Pieterse, G. M. \& van Vuren, J. H. (2004) Histological evidence of intersex in feral sharptooth catfish (Clarias gariepinus) from an estrogen-polluted water source in Gauteng, South Africa. Environmental Toxicology, Vol.19, No.6, (December 2004), pp. 603-608, ISSN1520-4081

Bergström, R.; Adami, H.O.; Möhner, M.; Zatonski, W.; Storm, H.; Ekbom, A.; Tretli, S.; Teppo, L.; Akre, O. \& Hakulinen, T. (1996) Increase in testicular cancer incidence in six European countries: a birth cohort phenomenon. The Journal of the National Cancer Institute, Vol.88, No.11, (June 1996), pp. 727-733, ISSN 0027-8874

Bernal, A. J. \& Jirtle, R. L. (2010) Epigenomic disruption: the effects of early developmental exposures. Birth defects research. Part A, Clinical and molecular teratology, Vol.88, No.10, (October 2010), pp. 938-944, ISSN 1542-0752

Berrevoets, C. A.; Umar, A. \& Brinkmann, A. O. (2002) Antiandrogens: selective androgen receptor modulators. Molecular and Cellular Endocrinology, Vol.198, No.1-2, (December 2002), pp. 97-103, ISSN 0303-7207

Bian, Q.; Qian, J.; Xu, L.; Chen, J.; Song, L. \& Wang, X. (2006) The toxic effects of 4-tertoctylphenol on the reproductive system of male rats. Food and Chemical Toxicology, Vol.44, No.8, (August 2006), pp. 1355-1361, ISSN 0278-6915

Bilinska B.; Lesniak M. \& Schmalz, B. (1997) Are ovine Leydig cells able to aromatize androgens? Reproduction, Fertility and Development, Vol.9, No.2, 193-199, ISSN, 10313613

Blake, C. A. \& Boockfor, F. R. (1997) Chronic administration of the environmental pollutant 4-tert-octylphenol to adult male rats interferes with the secretion of luteinizing hormone, follicle-stimulating hormone, prolactin, and testosterone. Biology of Reproduction, Vol.57, No.2, (August 1997), pp. 255-266, ISSN 0006-3363

Blake, C. A.; Boockfor, F. R.; Nair-Menon, J. U.; Millette, C. F.; Raychoudhury, S. S. \& McCoy, G. L. (2004) Effects of 4-tert-octylphenol given in drinking water for 4 
months on the male reproductive system of Fischer 344 rats. Reproductive Toxicology, Vol.18, No.1, (January-February 2004), pp. 43-51, ISSN 0890-6238

Blystone, C. R.; Lambright, C. S.; Howdeshell, K. L.; Furr, J.; Sternberg, R. M.; Butterworth, B. C.; Durhanm, E. J.; Makynen, E. A.; Ankley, G. T.; Wilson, V. S.; Leblanc, G. A. \& Gray, L. E. Jr. (2007) Sensitivity of fetal rat testicular steroidogenesis to maternal prochloraz exposure and the underlying mechanism of inhibition. Toxicological Sciences, Vol.97, No.2, (June 2007),pp. 512-519, ISSN 1096-6080

Blystone, C. R.; Lambright, C. S.; Howdeshell, K. L.; Furr, J.; Sternberg, R. M.; Butterworth, B. C.; Durhan, E. J.; Makynen, E. A.; Ankley, G. T.; Wilson, V. S.; Leblanc, G. A. \& Gray, L. E. Jr. (2007) Sensitivity of fetal rat testicular steroidogenesis to maternal prochloraz exposure and the underlying mechanism of inhibition. Toxicological Sciences, Vol.97, No.2, (June 2007), pp. 512-519, ISSN 1096-6080

Boisen, K. A.; Kaleva, M.; Main, K. M.; Virtanen, H. E.; Haavisto, A. M.; Schmidt, I. M.; Chellakooty, M.; Damgaard, I. N.; Mau, C.; Reunanen, M.; Skakkebaek, N. E. \& Toppari, J. (2004) Difference in prevalence of congenital cryptorchidism in infants between two Nordic countries. Lancet, Vol.363, No.9417, (April 2004), pp. 12641269, ISSN 0140-6736

Boockfor, F.R. \& Blake, C.A. (1997) Chronic administration of 4-tert-octylphenol to adult male rats causes shrinkage of the testes and male accessory sex organs, disrupts spermatogenesis, and increases the incidence of sperm deformities. Biology of Reproduction, Vol.57, No.2, (August 1997), pp. 267-277, ISSN 0006-3363

Borch, J.; Metzdorff, S. B.; Vinggaard, A. M.; Brokken, L. \& Dalgaard, M. (2006) Mechanisms underlying the anti-androgenic effects of diethylhexyl phthalate in fetal rat testis. Toxicology, Vol.223, No.1-2, (June 2006), pp. 144-155, ISSN 0300-483X

Bouskine, A.; Nebout, M.; Brücker-Davis, F.; Benahmed, M. \& Fenichel, P. (2009) Low doses of bisphenol A promote human seminoma cell proliferation by activating PKA and PKG via a membrane G-protein-coupled estrogen receptor. Environmental Health Perspectives, Vol.117, No.7, (July 2009), pp. 1053-1058, ISSN 0091-6765

Braunstein, G. D.; Dahlgren, J. \& Loriaux, D. L. (1978) Hypogonadism in chronically leadpoisoned men. Infertility, Vol.1, No.1, pp. 33-51, ISSN 1203-3243

Brokken, L. J.; Adamsson, A.; Paranko, J. \& Toppari, J. (2009) Antiandrogen exposure in utero disrupts expression of desert hedgehog and insulin-like factor 3 in the developing fetal rat testis. Endocrinology, Vol.150, No.1, (January 2009), pp. 445-451, ISSN 0013-7227

Bubenik, G. A.; Jacobson, J. P.; Schams, K. D. \& Bartoš, L. (2001) Cryptorchidism, hypogonadism and antler malformation in black-tailed deer (Odocoileus hemionus sitkensis) of Kodiak Island. Zeitschrift für Jagdwissenschaft, Vol.47, No.4, (December 2001), pp. 241-252, ISSN 0044-2887

Bulayeva, N. N. \& Watson, C. S. (2004) Xenoestrogen-induced ERK-1 and ERK-2 activation via multiple membrane-initiated signaling pathways. Environmental Health Perspectives, (November 2004), Vol.112, No.15, pp.1481-1487, ISSN 0091-6765

Calafat, A.M.; Ye, X.; Wong, L. Y.; Reidy, J. A.; Needham, L. L. (2008) Exposure of the U.S. population to bisphenol A and 4-tertiary-octylphenol: 2003-2004. Environmental Health Perspectives, Vol.116, No.1, (January 2008), pp. 39-44, ISSN 0091-6765

Cardoso, N.; Pandolfi, M.; Lavalle, J.; Carbone, S.; Ponzo, O.; Scacchi, P. \& Reynoso, R. (2011) Probable gamma-aminobutyric acid involvement in bisphenol $\mathrm{A}$ effect at the 
hypothalamic level in adult male rats. Journal of Physiology \& Biochemistry, (June 2011), doi: 10.1007/s13105-011-0102-6, ISSN 1138-7548

Carlsen, E.; Giwercman, A.; Keiding, N. \& Skakkebaek, N. E. (1992) Evidence for decreasing quality of semen during past 50 years. British Medical Journal, Vol.305, No.6854, (September 1992), pp. 609-613, ISSN 09598138

Carreau, S.; Lambard, S.; Delalande, C.; Denis-Galeraud, I.; Bilinska, B. \& Bourguiba, S. (2003) Aromatase expression and role of estrogens in male gonad : a review. Reproductive Biology and Endocrinology, Vol.1: 35, (April 2003), ISSN 1477-7827

Chang, H. S.; Anway, M. D.; Rekow, S. S. \& Skinner, M. K. (2006) Transgenerational epigenetic imprinting of the male germline by endocrine disruptor exposure during gonadal sex determination. Endocrinology, Vol.147, No.12, (December 2006), pp. 5524-5541, ISSN 0013-7227

Chapin, R. E.; Harris, M. W.; Davis, B. J.; Ward, S. M.; Wilson, R. E.; Mauney, M. A.; Lockhart, A. C.; Smialowicz, R. J.; Moser, V. C.; Burka, L. T. \& Collins, B. J. (1997) The effects of perinatal/juvenile methoxychlor exposure on adult rat nervous, immune, and reproductive system function. Fundamental and Applied Toxicology, Vol.40, No.1, (November 1997), pp. 138-157, ISSN 0272-0590

Colborn, T. \& Clement, C. (Eds.). (1992) Chemically-induced alterations in sexual and functional development - the wildlife/human connection, Princeton Scientific Pub., ISBN 0-91113135-3, Princeton

Colborn, T.; vom Saal, F. S. \& Soto, A. M. (1993) Developmental effects of endocrinedisrupting chemicals in wildlife and humans. Environmental Health Perspectives, Vol.101, No.5, (October 1993), pp. 378-384, ISSN 0091-6765

Cook, J. C.; Mullin, L. S.; Frame, S. R. \& Biegel, L. B. (1993) Investigation of a mechanism for Leydig cell tumorigenesis by linuron in rats. Toxicology and Applied Pharmacology, (April 1993), Vol.119, No.2, pp. 195-204, ISSN 0041-008X

Cowin, P. A.; Gold, E.; Aleksova, J.; O'Bryan, M. K.; Foster, P. M.; Scott, H. S. \& Risbridger, G. P. (2010) Vinclozolin exposure in utero induces postpubertal prostatitis and reduces sperm production via a reversible hormone-regulated mechanism. Endocrinology, Vol.151, No.2, (February 2010), pp. 783-792, ISSN 0013-7227

Crews, D. \& McLachlan, J. A. (2006) Epigenetics, evolution, endocrine disruption, health, and disease. Endocrinology, Vol.147, Suppl.6, (June 2006), pp. S4-10, ISSN 0013-7227

Cummings, A. M. (1997) Methoxychlor as a model for environmental estrogens. Critical Reviews in Toxicology, Vol.27, No.4, (July 1997), pp. 367-379, ISSN 1040-8444

Davenport, M. (1997) Risk of testicular cancer in boys with cryptorchidism. Study was based on small number of cancers. British Medical Journal, Vol.315, No.7120, (November 1997), pp. 1462-1463, ISSN 09598138

Davenport, M. (1997) Risk of testicular cancer in boys with cryptorchidism. Study was based on small number of cancers. British Medical Journal, Vol.315, No.7120, (November 1997), pp. 1462-1463, ISSN 0959-8138

de Solla, S. R.; Bishop, C.A.; Van der Kraak, G. \& Brooks, R. J. (1998) Impact of organochlorine contamination on levels of sex hormones and external morphology of common snapping turtles (Chelydra serpentina serpentina) in Ontario, Canada. Environmental Health Perspectives, Vol.106, No.5, (May 1998), pp. 253-260, ISSN 00916765 
de Solla, S. R.; Martin, P. A.; Fernie, K. J.; Park, B. J. \& Mayne, G. (2006) Effects of environmentally relevant concentrations of atrazine on gonadal development of snapping turtles (Chelydra serpentina). Environmental Toxicology \& Chemistry, Vol.25, No.2, (February 2006), pp. 520-526, ISSN, 0730-7268

de Souza Predes, F.; Diamante, M. A. \& Dolder, H. (2010) Testis response to low doses of cadmium in Wistar rats. International Journal of Experimental Pathology, Vol.91, No.2, (April 2010), pp.125-131, ISSN 0959-9673

Dehal, S. S. \& Kupfer, D. (1994) Metabolism of the proestrogenic pesticide methoxychlor by hepatic P450 monooxygenases in rats and humans. Dual pathways involving novel ortho ring-hydroxylation by CYP2B. Drug Metabolism and Disposition, Vol.22, No.6, (November-December 1994), pp. 937-946, ISSN 0090-9556

Delbès, G.; Levacher, C. \& Habert, R. (2006) Estrogen effects on fetal and neonatal testicular development. Reproduction, Vol.132, No.4, (October 2006), pp. 527-538, ISSN 14701626

Delbès, G.; Levacher, C.; Duquenne, C.; Racine, C.; Pakarinen, P. \& Habert, R. (2005) Endogenous estrogens inhibit mouse fetal Leydig cell development via estrogen receptor alpha. Endocrinology, (May 2005), Vol.146, No.5, pp. 2454-2461, ISSN 00137227

Diamanti-Kandarakis, E.; Bourguignon, J. P.; Giudice, L. C.; Hauser, R.; Prins, G. S.; Soto, A. M.; Zoeller, R. T. \& Gore, A. C. (2009) Endocrine-disrupting chemicals: an Endocrine Society scientific statement. Endocrine Reviews, Vol.30, No.4, (June 2009), pp. 293-342, ISSN 0163-769X

Dieckmann, K. P. \& Pichlmeier, U. (2004) Clinical epidemiology of testicular germ cell tumors. World Journal of Urology , Vol.22, No.1, (April 2004), pp. 2-14, ISSN 07244983

Dohle, G. R.; Smit, M. \& Weber, R. F. (2003) Androgens and male fertility. World Journal of Urology, Vol.21, No.5, (November 2003), pp. 341-345, ISSN1433-8726

Driscoll, S. G. \& Taylor, S. H. (1980) Effects of prenatal maternal estrogen on the male urogenital system. Obstetrics and Gynecology, Vol.56, No.5, (November 1980), pp. 537-542, ISSN 0029-7844

Durlej, M.; Kopera, I.; Knapczyk-Stwora, K.; Hejmej, A.; Duda, M.; Koziorowski, M.; Slomczynska, M. \& Bilinska, B. (2011) Acta Histochemica, Vol.113, No.1, (January 2011), pp. 6-12, ISSN 0065-1281

Fisher, J. S. (2004a) Environmental anti-androgens and male reproductive health: focus on phthalates and testicular dysgenesis syndrome. Reproduction, Vol.127, No.3, (March 2004), pp. 305-315, ISSN 1470-1626

Fisher, J. S. (2004b) Are all EDC effects mediated via steroid hormone receptors? Toxicology, Vol.205, No.1-2, (December 2004), pp. 33-41, ISSN 0300-483X

Fisher, J. S.; Macpherson, S.; Marchetti, N. \& Sharpe, R. M. (2003) Human 'testicular dysgenesis syndrome': a possible model using in-utero exposure of the rat to dibutyl phthalate. Human Reproduction, Vol.18, No.7, (July 2003), pp. 1383-1394, ISSN 0268-1161

Fisher, J. S.; Turner, K. J.; Brown, D. \& Sharpe, R. M. (1999) Effect of neonatal exposure to estrogenic compounds on development of the excurrent ducts of the rat testis through puberty to adulthood. Environmental Health Perspectives, Vol.107, No.5, (May 1999), pp. 397-405, ISSN 0091-6765 
Foster, W. G.; Singh, A.; McMahon, A. \& Rice, D. C. (1998) Chronic lead exposure effects in the cynomolgus monkey (Macaca fascicularis) testis. Ultrastructural Pathology, Vol.22, No.1, (January-February 1998), pp. 63-71, ISSN 0191-3123

Fowler, K. A.; Gill, K.; Kirma, N.; Dillehay, D. L. \& Tekmal, R. R. (2000) Overexpression of aromatase leads to development of testicular Leydig cell tumors : an in vivo model for hormone-mediated testicular cancer. American Journal of Pathology, Vol.156, No.1, (January 2000), pp. 347-353, ISSN 0002-9440

Frederiksen, H.; Skakkebaek, N. E. \& Andersson, A. M. (2007) Metabolism of phthalates in humans. Molecular Nutrition E Food Research, Vol.51, No.7, (July 2007), pp. 899-911, ISSN 1613-4125

Fry, D. M. (1995) Reproductive effects in birds exposed to pesticides and industrial chemicals. Environmental Health Perspectives, Vol.103, Suppl. 7, (October 1995), pp. 165-171, ISSN 0091-6765

Gaido, K. W.; Leonard, L. S.; Maness, S. C.; Hall, J. M.; McDonnell, D. P.; Saville, B. \& Safe, S. (1999) Differential interaction of the methoxychlor metabolite 2,2-bis-(phydroxyphenyl)-1,1,1-trichloroethane with estrogen receptors alpha and beta. Endocrinology, Vol.140, No.12, (December 1999), pp. 5746-5753, ISSN 0013-7227

Gaido, K. W.; Maness, S. C.; McDonnell, D. P.; Dehal, S. S.; Kupfer, D. \& Safe, S. (2000) Interaction of methoxychlor and related compounds with estrogen receptor alpha and beta, and androgen receptor: structure-activity studies. Molecular Pharmacology, Vol.58, No.4, (October 2000), pp. 852-858, ISSN 0026-895X

Gancarczyk, M.; Paziewska-Hejmej, A.; Carreau, S.; Tabarowski, Z. \& Bilinska, B. (2004) Dose- and photoperiod-dependent effects of 17beta-estradiol and the anti-estrogen ICI 182,780 on testicular structure, acceleration of spermatogenesis, and aromatase immunoexpression in immature bank voles. Acta Histochemica, Vol.106, No.4, pp. 269-278, ISSN 0065-1281

Gebara, A. B.; Ciscato, C. H.; Monteiro, S. H. \& Souza, G. S. (2011) Pesticide residues in some commodities: dietary risk for children. Bulletin of Environmental Contamination and Toxicology, Vol.86, No.5, (May 2011), pp. 506-510, ISSN 0007-4861

Gehm, B. D.; McAndrews, J. M.; Chien, P. Y. \& Jameson, J. L. (1997) Resveratrol, a polyphenolic compound found in grapes and wine, is an agonist for the estrogen receptor. Proceedings of the National Academy of Sciences USA, Vol.94, No.25, (December 1997), pp. 14138-14143, ISSN 0027-8424

Gill, W. B.; Schumacher, G. F.; Bibbo, M.; Straus, F. H. 2nd \& Schoenberg, H. W. (1979) Association of diethylstilbestrol exposure in utero with cryptorchidism, testicular hypoplasia and semen abnormalities. Journal of Urology, Vol.122, No.1, (July 1979), pp. 36-39, ISSN1433-8726

Gong, Y. \& Han, X. D. (2006) Effect of nonylphenol on steroidogenesis of rat Leydig cells. Journal of Environmental Science and Health, Part B, Vol.41, No.5, pp. 705-715, ISSN 0360-1234

Gould, J. C.; Leonard, L. S.; Maness, S. C.; Wagner, B. L.; Conner, K.; Zacharewski, T.; Safe, S.; McDonnell, D. P. \& Gaido, K. W. (1998) Bisphenol A interacts with the estrogen receptor alpha in a distinct manner from estradiol. Molecular and Cellular Endocrinology, Vol.142, No.1-2, (July 1998), pp. 203-214, ISSN 0303-7207

Gray, L. E. Jr; Ostby, J. S. \& Kelce, W. R. (1994) Developmental effects of an environmental antiandrogen: the fungicide vinclozolin alters sex differentiation of the male rat. 
Toxicology and Applied Pharmacology, Vol.129, No.1, (November 1994), pp. 4652,ISSN 0041-008X

Gray, L. E. Jr; Wilson, V. S.; Stoker, T.; Lambright, C.; Furr, J.; Noriega, N.; Howdeshell, K.; Ankley, G. T. \& Guillette, L. (2006) Adverse effects of environmental antiandrogens and androgens on reproductive development in mammals. International Journal of Andrology, Vol.29, No.1, (February 2006), pp. 96-104, ISSN 0105-6263

Gray, L. E. Jr; Wolf, C.; Lambright, C.; Mann, P.; Price, M.; Cooper, R. L. \& Ostby, J. (1999) Administration of potentially antiandrogenic pesticides (procymidone, linuron, iprodione, chlozolinate, p,p'-DDE, and ketoconazole) and toxic substances (dibutyland diethylhexyl phthalate, PCB 169, and ethane dimethane sulphonate) during sexual differentiation produces diverse profiles of reproductive malformations in the male rat. Toxicology and Industrial Health, (January-March 1999), Vol.15, No.1-2, pp. 94-118, ISSN: 0748-2337

Guillette, L. J. Jr; Gross, T. S.; Masson, G. R.; Matter, J. M.; Percival, H. F. \& Woodward, A. R. (1994) Developmental abnormalities of the gonad and abnormal sex hormone concentrations in juvenile alligators from contaminated and control lakes in Florida. Environmental Health Perspectives, Vol.102, No.8, (August 1994), pp. 680-688, ISSN 0091-6765

Han, X. D.; Tu, Z. G.; Gong, Y.; Shen, S. N.; Wang, X. Y.; Kang, L. N.; Hou, Y. Y. \& Chen, J. X. (2004) The toxic effects of nonylphenol on the reproductive system of male rats. Reproductive Toxicology, Vol.19, No.2, (December 2004), pp. 215-221, ISSN 0890-6238

Hejmej, A.; Kopera, I.; Kotula-Balak, M.; Lydka, M.; Lenartowicz, M. \& Bilinska, B. (2011a) Are expression and localization of tight and adherens junction proteins in testes of adult boar affected by foetal and neonatal exposure to flutamide? Reproductive Toxicology, doi:10.1111/j.1365-2605.2011.01206.x, ISSN 0890-6238

Hejmej, A.; Kotula-Balak, M.; Galas, J. \& Bilinska, B. (2011b) Effects of 4-tert-octylphenol on the testes and seminal vesicles in adult male bank voles. Reproductive Toxicology, Vol.31, No.1, (January 2011), pp. 95-105, ISSN 0890-6238.

Henley, D. V. \& Korach, K. S. (2010) Physiological effects and mechanisms of action of endocrine disrupting chemicals that alter estrogen signaling. Hormones (Athens), Vol.9, No.3, (July-September 2010), pp. 191-205, ISSN 1109-3099

Henley, D. V.; Lipson, N.; Korach, K. S. \& Bloch, C. A. (2007) Prepubertal gynecomastia linked to lavender and tea tree oils. New England Journal of Medicine, Vol.356, No.5, (February 2007), pp. 479-485, ISSN 0028-4793

Hess, R. A. (2000) Oestrogen in fluid transport in efferent ducts of the male reproductive tract. Reviews of Reproduction, Vol.5, No.2, (May 2000), pp. 84-92, ISSN 1359-6004

Hess, R. A. (2003) Estrogen in the adult male reproductive tract: a review. Reproductive Biology and Endocrinology, Vol.1: 52, (July 2003), ISSN 0196-9781

Hess, R. A.; Bunick, D.; Lee, K. H.; Bahr, J.; Taylor, J. A.; Korach, K. S. \& Lubahn, D. B. (1997) A role for oestrogens in the male reproductive system. Nature, (December 1997), Vol.390, No.6659, pp. 509-512, ISSN 0028-0836

Hodgson, M. C.; Shen, H. C.; Hollenberg, A. N. \& Balk, S. P. (2008) Structural basis for nuclear receptor corepressor recruitment by antagonist-liganded androgen receptor. Molecular Cancer Therapeutics, Vol.7, No.10, (October 2008), pp. 3187-3194, ISSN 1535-7163 
Hosokawa, S.; Murakami, M.; Ineyama, M.; Yamada, T.; Koyama, Y.; Okuno, Y.; Yoshitake, A.; Yamada, H. \& Miyamoto, J. (1993) Effects of procymidone on reproductive organs and serum gonadotropins in male rats. Journal of Toxicological Sciences, Vol.18, No.2, (May 1993), pp. 111-124, ISSN 0388-1350

Howdeshell, K. L.; Furr, J.; Lambright, C. R.; Rider, C. V.; Wilson, V. S. \& Gray, L. E. Jr. (2007) Cumulative effects of dibutyl phthalate and diethylhexyl phthalate on male rat reproductive tract development: altered fetal steroid hormones and genes. Toxicological Sciences, Vol.99, No.1, (September 2007), pp. 190-202, ISSN 1096-6080

Hu, G. X.; Zhao, B.; Chu, Y.; Li, X. H.; Akingbemi, B. T.; Zheng, Z. Q. \& Ge, R. S. (2011) Effects of methoxychlor and 2,2-bis(p-hydroxyphenyl)-1,1,1-trichloroethane on 3 $\beta$ hydroxysteroid dehydrogenase and $17 \beta$-hydroxysteroid dehydrogenase- 3 activities in human and rat testes. International Journal of Andrology, Vol.34, No.2, (April 2011), pp. 138-144, ISSN 0105-6263

Izumi, Y.; Yamaguchi, K.; Ishikawa, T.; Ando, M.; Chiba, K.; Hashimoto, H.; Shiotani, M. \& Fujisawa, M. (2011) Molecular changes induced by bisphenol-A in rat Sertoli cell culture. Systems Biology in Reproductive Medicine, (May 2011), doi: 10.3109/19396368.2011.574248, ISSN 1939-6368

Ji, Y. L.; Wang, H.; Liu, P.; Wang, Q.; Zhao, X. F.; Meng, X. H.; Yu, T.; Zhang, H.; Zhang, C.; Zhang, Y. \& Xu, D. X. (2010) Pubertal cadmium exposure impairs testicular development and spermatogenesis via disrupting testicular testosterone synthesis in adult mice. Reproductive Toxicology,Vol.29, No.2, (April 2010), pp. 176-183, ISSN 0890-6238

Ji, Y. L.; Wang, H.; Liu, P.; Zhao, X. F.; Zhang, Y.; Wang, Q.; Zhang, H.; Zhang, C.; Duan, Z. H.; Meng, C. \& Xu, D. X. (2011) Effects of maternal cadmium exposure during late pregnant period on testicular steroidogenesis in male offspring. Toxicology Letters, Vol.205, No.1, (August 2011), pp. 69-78, ISSN 0378-4274

Jie, X.; Yang, W.; Jie, Y.; Hashim, J. H.; Liu, X. Y.; Fan, Q. Y. \& Yan, L. (2010) Toxic effect of gestational exposure to nonylphenol on F1 male rats. Birth Defects Research Part B Development Reproductive Toxicology, Vol.89, No.5, (October 2010), pp. 418-428, ISSN 1542-9733

Jobling, S.; Beresford, N.; Nolan, M.; Rodgers-Gray, T.; Brighty, G.C.; Sumpter, J.P. \& Tyler, C.R. (2002) Altered sexual maturation and gamete production in wild roach (Rutilus rutilus) living in rivers that receive treated sewage effluents. Biology of Reproduction, Vol.66, No.2, (February 2002), pp. 272-281, ISSN 0006-3363

Johnson, L.; Staub, C.; Silge, R. L.; Harris, M. W. \& Chapin, R. E. (2002) The pesticide methoxychlor given orally during the perinatal/juvenile period, reduced the spermatogenic potential of males as adults by reducing their Sertoli cell number. Reproduction, Nutrition and Development, Vol.42, No.6, (November-December 2002), pp. 573-580, ISSN 0926-5287

Jørgensen, N.; Andersen, A.G; Eustache, F.; Irvine, D. S.; Suominen, J.; Petersen, J. H.; Andersen, A. N.; Auger, J.; Cawood, E. H.; Horte, A.; Jensen, T. K.; Jouannet, P.; Keiding, N.; Vierula, M.; Toppari, J. \& Skakkebaek, N. E. (2001) Regional differences in semen quality in Europe. Human Reproduction, Vol.16, No.5, (May 2001), pp. 1012-1019, ISSN 1355-4786

Jørgensen, N.; Asklund, C.; Carlsen, E. \& Skakkebaek, N. E. (2006) Coordinated European investigations of semen quality: results from studies of Scandinavian young men is 
a matter of concern. International Journal of Andrology, Vol.29, No.1, (February 2006), pp. 54-61, ISSN 0105-6263

Jørgensen, N.; Vierula, M.; Jacobsen, R.; Pukkala, E.; Perheentupa, A.; Virtanen, H. E.; Skakkebaek, N. E. \& Toppari, J. (2011) Recent adverse trends in semen quality and testis cancer incidence among Finnish men. International Journal of Andrology, (March 2011), doi: 10.1111/j.1365-2605.2010.01133.x. ISSN 0105-6263

Källén, B.; Bertollini, R.; Castilla, E.; Czeizel, A.; Knudsen, L. B.; Martinez-Frias, M. L.; Mastroiacovo, P. \& Mutchinick, O. (1986) A joint international study on the epidemiology of hypospadias. Acta Pediatrica Scandinavica. Supplement, Vol.324, pp. 1-52, ISSN 0300-8843

Kelce, W. R. \& Wilson, E. M. (1997) Environmental antiandrogens: developmental effects, molecular mechanisms, and clinical implications. Journal of Molecular Medicine, Vol.75, No.3, (March 1997), pp. 198-207, ISSN 0946-2716

Kelce, W. R.; Stone, C. R.; Laws, S. C.; Gray, L. E.; Kemppainen, J. A. \& Wilson, E. M. (1995) Persistent DDT metabolite p,p'-DDE is a potent androgen receptor antagonist. Nature, Vol.375, No.6532, (June 1995), pp. 581-585, ISSN 0028-0836

Kim, J. Y.; Han, E. H.; Kim, H. G.; Oh, K. N.; Kim, S. K.; Lee, K. Y. \& Jeong, H. G. (2010) Bisphenol A-induced aromatase activation is mediated by cyclooxygenase-2 upregulation in rat testicular Leydig cells. Toxicology Letters, Vol.193, No.2, (March 2010), pp. 200-208, ISSN 0378-4274

Kim, S. K.; Kim, J. H.; Lee, H. J. \& Yoon, Y. D. (2007) Octylphenol reduces the expressions of steroidogenic enzymes and testosterone production in mouse testis. Environmental Toxicology, Vol.22, No.5, (October 2007), pp. 449-458, ISSN 1520-4081

Kopera, I.; Durlej, M.; Hejmej, A.; Knapczyk-Stwora K.; Duda, M.; Slomczynska, M. \& Bilinska, B. (2011) Differential Expression of Connexin 43 in Adult Pig Testes During Normal Spermatogenic Cycle and After Flutamide Treatment. Reproduction in Domestic Animals, doi: 10.1111/j.1439-0531.2011.01783.x, ISSN 0936-6768

Kopera, I.; Durlej, M.; Hejmej, A.; Knapczyk-Stwora K.; Duda, M.; Slomczynska, M.; Koziorowski, M. \& Bilinska, B. (2010) Effects of pre- and postnatal exposure to flutamide on connexin 43 expression in testes and ovaries of prepubertal pigs. European Journal of Histochemistry, Vol.54, No.2, (April 2010), pp. e15, ISSN 1121$760 \mathrm{X}$

Kotula-Balak, M.; Pochec, E.; Hejmej, A.; Duda, M. \& Bilinska, B. (2011) Octylphenol affects morphology and steroidogenesis in mouse tumor Leydig cells. Toxicology In Vitro, Vol.25, No.5, (August 2011), pp. 1018-1026, ISSN 0887-2333

Kris-Etherton, P. M.; Hecker, K. D.; Bonanome, A.; Coval, S. M.; Binkoski, A. E.; Hilpert, K. F.; Griel, A. E. \& Etherton, T. D. (2002) Bioactive compounds in foods: their role in the prevention of cardiovascular disease and cancer. American Journal of Medicine Vol.113, Suppl.9B, (December 2002), pp. 71S-88S, ISSN 0002-9343

Kuiper, G. G.; Enmark, E.; Pelto-Huikko, M.; Nilsson, S. \& Gustafsson J. A. (1996) Cloning of a novel receptor expressed in rat prostate and ovary. The Proceedings of the National Academy of Science U S A, Vol.93, No.12, (June 1996),pp. 5925-5930, ISSN 0027-8424

Kuiper, G. G.; Lemmen, J. G.; Carlsson, B.; Corton, J. C.; Safe, S. H.; van der Saag, P. T.; van der Burg, B. \& Gustafsson, J. A. (1998) Interaction of estrogenic chemicals and phytoestrogens with estrogen receptor beta. Endocrinology, Vol.139, No.10, (October 1998), pp. 4252-4263, ISSN 0013-7227 
Kundakovic, M. \& Champagne, F. A. (2011) Epigenetic perspective on the developmental effects of bisphenol A. Brain, Behavior, and Immunity, (February 2011), doi:10.1016/j.bbi.2011.02.005, ISSN 0889-1591

Laguë, E . \& Tremblay, J. J. (2008) Antagonistic effects of testosterone and the endocrine disruptor mono-(2-ethylhexyl) phthalate on INSL3 transcription in Leydig cells. Endocrinology, Vol.149, No.9, (September 2008), pp. 4688-4694, ISSN 0013-7227

Laier, P.; Metzdorff, S. B.; Borch, J.; Hagen, M. L.; Hass, U.; Christiansen, S.; Axelstad, M.; Kledal, T.; Dalgaard, M.; McKinnell, C,.; Brokken, L. J. \& Vinggaard, A. M. (2006) Mechanisms of action underlying the antiandrogenic effects of the fungicide prochloraz. Toxicology and Applied Pharmacology, (June 2006), Vol.213, No.2, pp. 160171, ISSN 0041-008X

Lambright, C.; Ostby, J.; Bobseine, K.; Wilson, V.; Hotchkiss, A. K.; Mann, P. C. \& Gray, L. E. Jr. (2000) Cellular and molecular mechanisms of action of linuron: an antiandrogenic herbicide that produces reproductive malformations in male rats. Toxicological Sciences, Vol.56, No.2, (August 2000), pp. 389-399, ISSN 1096-6080

Lee, B. J.; Jung, E. Y.; Yun, Y.W.; Kang, J. K.; Baek, I. J.; Yon, J. M.; Lee, Y. B.; Sohn, H. S.; Lee, J. Y.; Kim, K. S. \& Nam, S. Y. (2004) Effects of exposure to genistein during pubertal development on the reproductive system of male mice. Journal of Reproduction and Development, Vol.50, No.4, (August 2004), pp. 399-409, ISSN 0916-8818

Lee, H. J.; Chattopadhyay, S.; Gong, E. Y.; Ahn, R. S. \& Lee, K. (2003) Antiandrogenic effects of bisphenol A and nonylphenol on the function of androgen receptor. Toxicological Sciences, Vol.75, No.1, (September 2003), pp. 40-46, ISSN 1096-6080

Lee, P. C. (1998) Disruption of male reproductive tract development by administration of the xenoestrogen, nonylphenol, to male newborn rats. Endocrine, Vol.9, No.1, (August 1998), pp. 105-111, ISSN 1355-008X

Lehraiki, A.; Chamaillard, C.; Krust, A.; Habert, R. \& Levacher, C. (2011) Genistein impairs early testosterone production in fetal mouse testis via estrogen receptor alpha. Toxicology In Vitro, (May 2011), doi:10.1016/j.tiv.2011.05.017, ISSN 0887-2333

Lehraiki, A.; Racine, C.; Krust, A.; Habert, R. \& Levacher, C. (2009) Phthalates impair germ cell number in the mouse fetal testis by an androgen- and estrogen-independent mechanism. Toxicological Sciences, Vol.111, No.2, (October 2009), pp. 372-382, ISSN 1096-6080

Levallet, J.; Bilinska, B.; Mittre, H.; Genissel, C.; Fresnel, J. \& Carreau, S. (1998) Expression and immunolocalization of functional cytochrome $\mathrm{P} 450$ aromatase in mature rat testicular cells. Biology of Reproduction, Vol.58, No.4, (April 1998), pp. 919-926, ISSN 0006-3363

Li, X.; Nokkala, E.; Yan, W.; Streng, T.; Saarinen, N.; Wärri, A.; Huhtaniemi. I.; Santti. R.; Mäkelä, S. \& Poutanen, M. (2001) Altered structure and function of reproductive organs in transgenic male mice overexpressing human aromatase. Endocrinology; Vol.142, No.6, (June 2001), pp. 2435-2442, ISSN 0013-7227

Lubahn, D. B.; Moyer, J. S.; Golding, T. S.; Couse, J. F.; Korach, K. S. \& Smithies, O. (1993) Alteration of reproductive function but not prenatal sexual development after insertional disruption of the mouse estrogen receptor gene. The Proceedings of the National Academy of Science U S A, Vol.90, No.23, (December 1993), pp. 11162-11166, ISSN 0027-8424 
Mackenzie, C. A.; Lockridge, A. \& Keith, M. (2005) Declining sex ratio in a first nation community. Environmental Health Perspectives, Vol.113, No.10, (October 2005), pp. 1295-1298, ISSN 0091-6765

Macleod, D. J.; Sharpe, R. M.; Welsh, M.; Fisken, M.; Scott, H. M.; Hutchison, G. R.; Drake, A. J. \& van den Driesche, S. (2010) Androgen action in the masculinization programming window and development of male reproductive organs. International Journal of Andrology, Vol.33, No.2, (April 2010), pp. 279-287, ISSN 0105-6263

Majdic, G.; Sharpe, R. M. \& Saunders, P. T. (1997) Maternal oestrogen/xenoestrogen exposure alters expression of steroidogenic factor-1 (SF-1/Ad4BP) in the fetal rat testis. Molecular and Cellular Endocrinology, Vol.127, No.1, (March 1997), pp. 91-98, ISSN 0303-7207

Majdic, G.; Sharpe, R. M.; O'Shaughnessy, P. J. \& Saunders, P. T. (1996) Expression of cytochrome P450 17alpha-hydroxylase/C17-20 lyase in the fetal rat testis is reduced by maternal exposure to exogenous estrogens. Endocrinology, Vol.137, No.3, (March 1996), pp. 1063-1070, ISSN 1477-7827

Mansfield, K. G. \& Land, E. D. (2002) Cryptorchidism in Florida panthers: prevalence, features, and influence of genetic restoration. Journal of Wildlife Diseases, Vol.38, No.4, (October 2002), pp. 693-698, ISSN 0090-3558

Marchlewicz, M.; Michalska, T. \& Wiszniewska, B. (2004) Detection of lead-induced oxidative stress in the rat epididymis by chemiluminescence. Chemosphere, (December 2004), Vol.57, No.10, pp. 1553-1562, ISSN 0045-6535

Marselos, M. \& Tomatis, L. (1992) Diethylstilboestrol: I, Pharmacology, Toxicology and carcinogenicity in humans. European Journal of Cancer, Vol.28A, No.6-7, pp. 11821189, ISSN 0014-2964

Maschio, L. R.; Cordeiro, R. S.; Taboga, S. R. \& Góes, R. M. (2010) Short-term antiandrogen flutamide treatment causes structural alterations in somatic cells associated with premature detachment of spermatids in the testis of pubertal and adult guinea pigs. Reproduction in Domestic Animals, (June 2010), Vol.45, No.3, pp. 516-524, ISSN 09366768

McEwen, B.S. \& Alves, S. E. (1999) Estrogen actions in the central nervous system. Endocrine Reviews, Vol.20, No.3, (June 1999), pp. 279-307, ISSN 0163-769X

McIntyre, B. S.; Barlow, N. J.; Sar, M.; Wallace, D. G. \& Foster, P. M. (2002a) Effects of in utero linuron exposure on rat Wolffian duct development. Reproductive Toxicology, Vol.16, No.2, (March-April 2002),pp. 131-139, ISSN 0890-6238

McIntyre, B. S.; Barlow, N. J.; Wallace, D. G.; Maness, S. C.; Gaido, K. W. \& Foster, P. M. (2000) Effects of in utero exposure to linuron on androgen-dependent reproductive development in the male Crl:CD(SD)BR rat. Toxicology and Applied Pharmacology, Vol.167, No.2, (September 2000), pp. 87-99, ISSN 0041-008X

McIntyre, B. S.; Barlow, N.J. \& Foster, P. M. (2002b) Male rats exposed to linuron in utero exhibit permanent changes in anogenital distance, nipple retention, and epididymal malformations that result in subsequent testicular atrophy. Toxicological Sciences, Vol.65, No.1, (January 2002), pp. 62-70, ISSN 1096-6080

McKinnell, C.; Atanassova, N.; Williams, K.; Fisher, J. S.; Walker, M.; Turner, K. J.; Saunders, P. T. K. \& Sharpe, R. M. (2001) Suppression of androgen action and the induction of gross abnormalities of the reproductive tract in male rats treated neonatally with 
diethylstilbestrol. Journal of Andrology, Vol.22, No.2, (March-April 2001), pp. 323338, ISSN 0105-6263

McLachlan, J. A. (2001) Environmental signaling: what embryos and evolution teach us about endocrine disrupting chemicals. Endocrine Reviews, Vol.22, No.3, (June 2001), pp. 319-341, ISSN 1945-7189

McLachlan, J. A.; Newbold, R. R.; Burow, M. E. \& Li, S. F. (2001) From malformations to molecular mechanisms in the male: three decades of research on endocrine disrupters. Acta Pathologica, Microbiologica et Immunologica Scandinavica, Vol.109, No.4, (April 2001), pp. 263-272, ISSN 0903-4641

Melnick, S.; Cole, P.; Anderson, D. \& Herbst, A. (1987) Rates and risks of diethylstilbestrolrelated clear-cell adenocarcinoma of the vagina and cervix. An update. New England Journal of Medicine, Vol.316, No.9, (February 1987), pp. 514-516, ISSN 00284793

Mikkilä, T. F.; Toppari, J. \& Paranko, J. (2006) Effects of neonatal exposure to 4-tertoctylphenol, diethylstilbestrol, and flutamide on steroidogenesis in infantile rat testis. Toxicological Sciences, Vol.91, No.2, (June 2006), pp. 456-466, ISSN 1096-6080

Mittendorf, R. (1995) Teratogen update: carcinogenesis and teratogenesis associated with exposure to diethylstilbestrol (DES) in utero. Teratology, Vol.51, No.6, (June 1995), pp. 435-445, ISSN 0040-3709

Mohler, M. L.; Bohl, C. E.; Jones, A.; Coss, C. C.; Narayanan, R.; He, Y.; Hwang, D. J.; Dalton, J. T. \& Miller, D. D. (2009) Nonsteroidal selective androgen receptor modulators (SARMs): dissociating the anabolic and androgenic activities of the androgen receptor for therapeutic benefit. Journal of Medicinal Chemistry, Vol.52, No.12, (June 2009), pp. 3597-3617, ISSN 0223-5234

Møller, H. \& Skakkebaek N. E. (1999) Risk of testicular cancer in subfertile men: case-control study. British Medical Journal,, Vol.318, No.7183, (February 1999), pp. 559-562, ISSN 09598138

Monosson, E.; Kelce, W. R.; Lambright, C.; Ostby, J. \& Gray, L. E. Jr. (1999) Peripubertal exposure to the antiandrogenic fungicide, vinclozolin, delays puberty, inhibits the development of androgen-dependent tissues, and alters androgen receptor function in the male rat. Toxicology and Industrial Health, Vol.15, No.1-2, (January-March 1999), pp. 65-79, ISSN: 0748-2337

Mueller, S. O. (2004) Xenoestrogens: mechanisms of action and detection methods. Analytical and Bioanalytical Chemistry, Vol.378, No.3, (February 2004), pp. 582-587, ISSN 16182642

Mueller, S. O.; Simon, S.; Chae, K.; Metzler, M. \& Korach, K. S. (2004) Phytoestrogens and their human metabolites show distinct agonistic and antagonistic properties on estrogen receptor alpha (ERalpha) and ERbeta in human cells. Toxicological Sciences, Vol.80, No.1, (July 2004), pp. 14-25, ISSN 1096-6080

Murakami, M.; Hosokawa, S.; Yamada, T.; Harakawa, M.; Ito, M.; Koyama, Y.; Kimura, J.; Yoshitake, A. \& Yamada, H. (1995) Species-specific mechanism in rat Leydig cell tumorigenesis by procymidone. Toxicology and Applied Pharmacology, Vol.131, No.2, (April 1995), pp. 244-252, ISSN 0041-008X

Murono, E. P. \& Derk, R. C. (2005) The reported active metabolite of methoxychlor, 2,2bis(p-hydroxyphenyl)-1,1,1-trichloroethane, inhibits testosterone formation by 
cultured Leydig cells from neonatal rats. Reproductive Toxicology, Vol.20, No.4, (November-December 2005), pp. 503-513, ISSN 0890-6238

Mylchreest, E. \& Foster, P. M. (2000) DBP exerts its antiandrogenic activity by indirectly interfering with androgen signaling pathways. Toxicology and Applied Pharmacology, Vol.168, No.2, (October 2000), pp. 174-175, ISSN 0041-008X

Mylchreest, E.; Sar, M.; Cattley, R. C. \& Foster, P. M. (1999) Disruption of androgenregulated male reproductive development by di(n-butyl) phthalate during late gestation in rats is different from flutamide. Toxicology and Applied Pharmacology, Vol.156, No.2, (April 1999), pp. 81-95, ISSN 0041-008X

Mylchreest, E.; Sar, M.; Wallace, D. G. \& Foster, P. M. (2002) Fetal testosterone insufficiency and abnormal proliferation of Leydig cells and gonocytes in rats exposed to di(nbutyl) phthalate. Reproductive Toxicology, Vol.16, No.1, (Jan-Feb 2002), pp. 19-28, ISSN 0890-6238

Nakamura, K.; Yasunaga, Y.; Ko, D.; Xu, L. L.; Moul, J. W.; Peehl, D. M.; Srivastava, S. \& Rhim, J. S. (2002) Cadmium-induced neoplastic transformation of human prostate epithelial cells. International Journal of Oncology, Vol.20, No.3, (March 2002), pp. 543547, ISSN 1019-6439

Nassar, N.; Bower, C. \& Barker, A. (2007) Increasing prevalence of hypospadias in Western Australia, 1980-2000. Archives of disease in childhood, Vol.92, No.7, (July 2007), pp. 580-584, ISSN 0003-9888

Neri, R. (1989) Pharmacology and pharmacokinetics of flutamide. Urology, Vol.34, Suppl.4, (October 1989), pp. 19-21, ISSN 0090-4295

Noriega, N. C.; Ostby, J.; Lambright, C.; Wilson, V. S. \& Gray, L. E. Jr. (2005) Late gestational exposure to the fungicide prochloraz delays the onset of parturition and causes reproductive malformations in male but not female rat offspring. Biology of Reproduction, Vol.72, No.6, (June 2005), pp. 1324-1335, ISSN 0006-3363

O'Connor, J. C.; Cook, J. C.; Slone, T. W.; Makovec, G. T.; Frame, S. R. \& Davis, L. G. (1998) An ongoing validation of a Tier I screening battery for detecting endocrine-active compounds (EACs). Toxicological Sciences, Vol.46, No.1, (November 1998), pp. 45-60, ISSN 1096-6080

Oettel, M. (2002) Is there a role for estrogens in the maintenance of men's health? Aging Male, (December 2002), Vol.5, No.4, pp. 248-257, ISSN 1368-5538

Omezzine, A.; Chater, S.; Mauduit, C.; Florin, A.; Tabone, E.; Chuzel, F.; Bars, R. \& Benahmed, M. (2003) Long-term apoptotic cell death process with increased expression and activation of caspase- 3 and -6 in adult rat germ cells exposed in utero to flutamide. Endocrinology, Vol.144, No.2, (February 2003), pp. 648-661, ISSN 0013-7227

Ostby, J.; Kelce, W. R.; Lambright, C.; Wolf, C. J.; Mann, P. \& Gray, L. E. Jr. (1999) The fungicide procymidone alters sexual differentiation in the male rat by acting as an androgen-receptor antagonist in vivo and in vitro. Toxicology and Industrial Health, Vol.15, No.1-2, (January-March 1999), pp. 80-93, ISSN: 0748-2337

Parks, L. G.; Ostby, J. S.; Lambright, C. R.; Abbott, B. D.; Klinefelter, G. R.; Barlow, N. J. \& Gray, L. E. Jr. (2000) The plasticizer diethylhexyl phthalate induces malformations by decreasing fetal testosterone synthesis during sexual differentiation in the male rat. Toxicological Sciences, Vol.58, No.2, (December 2000), pp. 339-349, ISSN 10966080 
Paulozzi, L. J. International trends in rates of hypospadias and cryptorchidism. (1999) Environmental Health Perspectives, Vol.107, No.4, (April 1999), pp. 297-302, ISSN 0091-6765

Prins, G. S.; Birch, L.; Couse, J. F.; Choi, I.; Katzenellenbogen, B. \& Korach, K. S. (2001) Estrogen imprinting of the developing prostate gland is mediated through stromal estrogen receptor alpha: studies with alphaERKO and betaERKO mice. Cancer Research, Vol.61, No.16, (August 2001), pp. 6089-6097, ISSN 0008-5472

Reinli, K. \& Block, G. (1996) Phytoestrogen content of foods - a compendium of literature values. Nutrition and Cancer, Vol.26, No.2, pp. 123-48, ISSN 0163-5581

Revel, A.; Raanani, H.; Younglai, E.; Xu, J.; Rogers, I.; Han, R.; Savouret, J. F. \& Casper, R. F. (2003) Resveratrol, a natural aryl hydrocarbon receptor antagonist, protects lung from DNA damage and apoptosis caused by benzo[a]pyrene. Journal of Applied Toxicology, Vol.23, No.4, (July-August 2003), pp. 255-261, ISSN 0260-437X

Richter, C. A.; Birnbaum, L. S.; Farabollini, F.; Newbold, R. R.; Rubin, B. S.; Talsness, C. E.; Vandenbergh, J. G.; Walser-Kuntz, D. R. \& vom Saal, F. S. (2007) In vivo effects of bisphenol A in laboratory rodent studies. Reproductive Toxicology, Vol.24, No.2, (August-September 2007), pp. 199-224, ISSN 0890-6238

Robertson, K. M.; O'Donnell, L.; Jones, M. E.; Meachem, S. J.; Boon, W. C.; Fisher, C. R.; Graves, K. H.; McLachlan, R. I. \& Simpson, E. R. (1999) Impairment of spermatogenesis in mice lacking a functional aromatase (cyp 19) gene. The Proceedings of the National Academy of Science U S A, Vol.96, No.14, (July 1999), pp. 7986-7991, ISSN 0027-8424

Rubin, M. M. (2007) Antenatal exposure to DES: lessons learned...future concerns. Obstetrical and Gynecological Survey, Vol.62, No.8, (August 2007),pp. 548-555, ISSN 0029-7828

Safe, S. (2004) Endocrine disruptors and human health: is there a problem. Toxicology, Vol.205, No.1-2, (December 2004), pp. 3-10, ISSN 0300-483X

Safe, S. H. (2000) Endocrine disruptors and human health--is there a problem? An update. Environmental Health Perspectives, Vol.108, No.6, (June 2000), pp. 487-493, ISSN 00916765

Scandinavica. Supplement, Vol.324, pp. 1-52, ISSN 0300-8843

Schettler, T. (2006) Human exposure to phthalates via consumer products. International Journal of Andrology, Vol.29, No.1, (February 2006), pp. 134-139, ISSN 0105-6263

Schmitt, E.; Dekant, W. \& Stopper, H. (2001) Assaying the estrogenicity of phytoestrogens in cells of different estrogen sensitive tissues. Toxicology In Vitro, Vol.15, No.4-5, (August-October 2001), pp. 433-439, ISSN 0887-2333

Setchell, K.D.; Zimmer-Nechemias, L.; Cai, J. \& Heubi, J. E. (1997) Exposure of infants to phyto-oestrogens from soy-based infant formula. Lancet, Vol.350, No.9070, (July 1997), pp. 23-7, ISSN 0140-6736

Sharpe, R. M. \& Irvine, D.S. (2004) How strong is the evidence of a link between environmental chemicals and adverse effects on human reproductive health? British Medical Journal, Vol.328, No.7437, (February 2004), pp. 447-451, ISSN 09598138

Sharpe, R. M. (2010) Environmental/lifestyle effects on spermatogenesis. Philosophical transactions of the Royal Society of London. Series B, Biological sciences, Vol.365, No.1546, (May 2010), pp. 1697-1712, ISSN 1471-2970 
Sharpe, R. M.; Atanassova, N.; McKinnell, C.; Parte, P.; Turner, K. J.; Fisher, J. S.; Kerr, J. B.; Groome, N. P.; Macpherson, S.; Millar, M. R. \& Saunders P. T. (1998) Abnormalities in functional development of the Sertoli cells in rats treated neonatally with diethylstilbestrol: a possible role for estrogens in Sertoli cell development. Biology of Reproduction, Vol.59, No.5, (November 1998), pp. 1084-1094, ISSN 0006-3363

Sharpe, R. M.; Rivas, A.; Walker, M.; McKinnell, C. \& Fisher, J. S. (2003) Effect of neonatal treatment of rats with potent or weak (environmental) oestrogens, or with a GnRH antagonist, on Leydig cell development and function through puberty into adulthood. International Journal of Andrology, Vol.26, No.1, (February 2003), pp. 2636, ISSN 0105-6263

Shi, Y. Q.; Li, H. W.; Wang, Y. P.; Liu, C. J. \& Yang, K. D. (2011) p,p'-DDE induces apoptosis and mRNA expression of apoptosis-associated genes in testes of pubertal rats. Environmental Toxicology, (March 2011), doi: 10.1002/tox.20694, ISSN1520-4081

Sikka, S. C. \& Wang, R. (2008) Endocrine disruptors and estrogenic effects on male reproductive axis. Asian Journal of Andrology, Vol.10, No.1, (January 2008), pp. 134145, ISSN 1008-682X

Singh, S. M.; Gauthier, S. \& Labrie, F. (2000) Androgen receptor antagonists (antiandrogens): structure-activity relationships. Current Medical Chemistry (February 2000), Vol.7, No.2, pp. 211-247, ISSN 0929-8673

Singleton, D. W. \& Khan, S. A. (2003) Xenoestrogen exposure and mechanisms of endocrine disruption. Frontiers in Bioscience, Vol.8, (January 2003), pp. s110-118, ISSN 10939946

Skakkebaek, N. E. \& Jørgensen, N. (2005) Testicular dysgenesis and fertility. Andrologia, Vol.37, No.6, (December 2005), pp. 217-218, ISSN 0303- 4569

Skakkebaek, N. E.; Rajpert-De Meyts, E. \& Main, K. M. (2001) Testicular dysgenesis syndrome: an increasingly common developmental disorder with environmental aspects. Human Reproduction, Vol.16, No.5, (May 2001), pp. 972-978, ISSN 0268-1161

Skinner, M.K. \& Anway, M. D. (2005) Seminiferous cord formation and germ-cell programming: epigenetic transgenerational actions of endocrine disruptors. Annals of the New York Academy of Sciences, Vol.1061, (December 2005), pp. 18-32, ISSN 0077-8923

Sokol, R. Z.; Madding, C. E. \& Swerdloff, R. S. (1985) Lead toxicity and the hypothalamicpituitary-testicular axis. Biology of Reproduction, Vol.33, No.3, (October 1985), pp. 722-728, ISSN 0006-3363

Sonne, C.; Leifsson, P. S.; Dietz, R.; Born, E. W.; Letcher, R. J.; Hyldstrup, L.; Riget, F. F.; Kirkegaard, M. \& Muir, D. C. (2006) Xenoendocrine pollutants may reduce size of sexual organs in East Greenland polar bears (Ursus maritimus). Environmental Science ETechnology (September 2006), Vol.40, No.18, pp. 5668-5674, ISSN 0013-936X

Staples, C. A.; Naylor, C. G.; Williams, J. B. \& Gledhill, W. E. (2001) Ultimate biodegradation of alkylphenol ethoxylate surfactants and their biodegradation intermediates. Environmental Toxicology \& Chemistry, Vol.20, No.11, (November 2001), pp. 24502455, ISSN 0730-7268

Stouder, C \& Paoloni-Giacobino, A. (2010) Specific transgenerational imprinting effects of the endocrine disruptor methoxychlor on male gametes. Reproduction, Vol.141, No.2, (February 2011), pp. 207-216, ISSN 1470-1626 
Stroheker, T.; Cabaton, N.; Nourdin, G.; Régnier, J. F.; Lhuguenot, J. C. \& Chagnon, M. C. (2005) Evaluation of anti-androgenic activity of di-(2-ethylhexyl)phthalate. Toxicology, Vol.208, No.1, (March 2005), pp. 115-121, ISSN 0300-483X

Suthar, A.C.; Banavalikar, M. M. \& Biyani, M. K. (2001) Pharmacological activities of Genistein, an isoflavone from soy (Glycine max): part II--anti-cholesterol activity, effects on osteoporosis \& menopausal symptoms. Indian Journal of Experimental Biology, Vol.39, No.6, (June 2001), pp. 520-525, ISSN 0019-5189

Suzuki, M.; Lee, H. C.; Chiba, S.; Yonezawa, T. \& Nishihara, M. (2004) Effects of methoxychlor exposure during perinatal period on reproductive function after maturation in rats. Journal of Reproduction and Development, Vol.50, No.4, (August 2004), pp. 455-461, ISSN 0916-8818

Svechnikov, K.; Izzo, G.; Landreh, L.; Weisser, J. \& Söder, O. (2010) Endocrine disruptors and Leydig cell function. Journal of Biomedicine and Biotechnology, Vol.2010: 684504, (August 2010), ISSN 1110-7243

Svechnikov, K.; Spatafora, C.; Svechnikova, I.; Tringali, C. \& Söder, O. (2009) Effects of resveratrol analogs on steroidogenesis and mitochondrial function in rat Leydig cells in vitro. Journal of Applied Toxicology, Vo.29, No.8, (November 2009), pp. 673680, ISSN 0260-437X

Svechnikov, K.; Supornsilchai, V.; Strand, M. L.; Wahlgren, A.; Seidlova-Wuttke, D.; Wuttke, W. \& Söder, O. (2005) Influence of long-term dietary administration of procymidone, a fungicide with anti-androgenic effects, or the phytoestrogen genistein to rats on the pituitary-gonadal axis and Leydig cell steroidogenesis. Journal of Endocrinology, Vol.187, No.1, (October 2005), pp. 117-124, ISSN 0022-0795

Swan, S. H.; Elkin, E.P. \& Fenster, L. (2000) The question of declining sperm density revisited: an analysis of 101 studies published 1934-1996. Environmental Health Perspectives, Vol.108, Vo.10, (October 2000), pp. 961-966, ISSN 0091-6765

Swan, S. H.; Kruse, R. L.; Liu, F.; Barr, D. B.; Drobnis, E.Z.; Redmon, J. B.; Wang, C.; Brazil, C.; Overstreet, J. W. \& Study for Future Families Research Group. (2003) Semen quality in relation to biomarkers of pesticide exposure. Environmental Health Perspectives, Vol.111, No.12, (September 2003), pp. 1478-1484, ISSN 0091-6765

Sweeney, T.; Nicol, L.; Roche, J. F. \& Brooks, A. N. (2000) Maternal exposure to octylphenol suppresses ovine fetal follicle-stimulating hormone secretion, testis size, and Sertoli cell number. Endocrinology, Vol.141, No.7, (July 2000), pp. 2667-2673, ISSN 00137227

Takiguchi, M. \& Yoshihara, S. (2006) New aspects of cadmium as endocrine disruptor. Environmental Sciences, Vol.13, No.2, pp. 107-116, ISSN 0915-955X

Thomas, P. \& Dong, J. (2006) Binding and activation of the seven-transmembrane estrogen receptor GPR30 by environmental estrogens: a potential novel mechanism of endocrine disruption. Journal of Steroid Biochemistry and Molecular Biology, Vol.102, No.1-5, (December 2006), pp. 175-179, ISSN 0960-0760

Thonneau, P.F.; Gandia, P. \& Mieusset, R. (2003) Cryptorchidism: incidence, risk factors, and potential role of environment; an update. International Journal of Andrology, Vol.24, No.2, (March-April 2003), pp. 155-162, ISSN 0105-6263

Toppari, J.; Kaleva, M. \& Virtanen, H. E. (2001) Trends in the incidence of cryptorchidism and hypospadias, and methodological limitations of registry-based data. Human Reproduction Update, Vol.7, No.3, (May-June 2001), pp. 282-286, ISSN 1355-4786 
Toyama, Y.; Hosoi, I.; Ichikawa, S.; Maruoka, M.; Yashiro, E.; Ito, H. \& Yuasa, S. (2001) Betaestradiol 3-benzoate affects spermatogenesis in the adult mouse. Molecular and Cellular Endocrinology, Vol.178, No.1-2, (June 2001), pp. 161-168, ISSN 0303-7207

Toyama, Y.; Suzuki-Toyota, F.; Maekawa, M.; Ito, C. \& Toshimori, K. (2004) Adverse effects of bisphenol A to spermiogenesis in mice and rats. Archives of Histology and Cytology, Vol.67, No.4, (November 2004), pp. 373-381, ISSN 0914-9465

Vaithinathan, S.; Saradha, B. \& Mathur, P. P. (2010) Methoxychlor induces apoptosis via mitochondria- and FasL-mediated pathways in adult rat testis. Chemico-Biological Interactions, Vol.185, No.2, (April 2010), pp. 110-118, ISSN 0009-2797

Vajda, A.M.; Barber, L. B.; Gray, J. L.; Lopez, E. M.; Woodling, J. D. \& Norris, D. O. (2008) Reproductive disruption in fish downstream from an estrogenic wastewater effluent. Environmental Science ETechnology, Vol.42, No.9, (May 2008), pp. 34073414, ISSN 0013-936X

van den Berg, H. (2009) Global status of DDT and its alternatives for use in vector control to prevent disease. Environmental Health Perspectives, Vol.117, No.11, (November 2009), pp. 1656-1663, ISSN 0091-6765

Van der Heiden, E.; Bechoux, N.; Muller, M.; Sergent, T.; Schneider, Y. J.; Larondelle, Y.; Maghuin-Rogister, G. \& Scippo, M. L. (2009) Food flavonoid aryl hydrocarbon receptor-mediated agonistic/antagonistic/synergic activities in human and rat reporter gene assays. Analytica Chimica Acta, Vol.637, No.1-2, (April 2009), pp. 337345, ISSN 0003-2670

Veeramachaneni, D. N.; Amann, R. P. \& Jacobson, J. P. (2006a) Testis and antler dysgenesis in sitka black-tailed deer on Kodiak Island, Alaska: Sequela of environmental endocrine disruption? Environmental Health Perspectives, Vol.114, Suppl. 1, (April 2006), pp. 51-59, ISSN 0091-6765

Veeramachaneni, D. N.; Palmer, J. S.; Amann, R. P.; Kane, C. M.; Higuchi, T. T. \& Pau, K. Y. (2006b) Disruption of sexual function, FSH secretion, and spermiogenesis in rabbits following developmental exposure to vinclozolin, a fungicide. Reproduction, Vol.131, No.4, (April 2006), pp. 805-816, ISSN 1470-1626

Vigueras-Villaseñor, R. M.; Moreno-Mendoza, N. A.; Reyes-Torres, G.; Molina-Ortiz, D.; León, M.C. \& Rojas-Castañeda J. C. (2006) The effect of estrogen on testicular gonocyte maturation. Reproductive Toxicology, Vol.22, No.3, (October 2006), pp. 513520, ISSN 0890-6238

Vinggaard, A. M.; Christiansen, S.; Laier, P.; Poulsen, M. E.; Breinholt, V.; Jarfelt, K.; Jacobsen, H.; Dalgaard, M.; Nellemann, C. \& Hass, U. (2005) Perinatal exposure to the fungicide prochloraz feminizes the male rat offspring. Toxicological Sciences, Vol.85, No.2, (June 2005), pp. 886-897, ISSN 1096-6080

Vinggaard, A. M.; Hass, U.; Dalgaard, M.; Andersen, H.R.; Bonefeld-Jørgensen, E.; Christiansen, S.; Laier, P. \& Poulsen, M. E. (2006) Prochloraz: an imidazole fungicide with multiple mechanisms of action. International Journal of Andrology, Vol.29, No.1, (February 2006), pp. 186-192, ISSN 0105-6263

Vinggaard, A. M.; Nellemann, C.; Dalgaard, M.; Jørgensen, E. B. \& Andersen, H. R. (2002) Antiandrogenic effects in vitro and in vivo of the fungicide prochloraz. Toxicological Sciences, Vol.69, No.2, (October 2002), pp. 344-353, ISSN 1096-6080

Vo, T. T.; Jung, E. M.; Dang, V. H.; Yoo, Y. M.; Choi, K. C.; Yu, F. H. \& Jeung, E. B. (2009) Di(2 ethylhexyl) phthalate and flutamide alter gene expression in the testis of 
immature male rats. Reproductive Biology and Endocrinology, Vol.7: 104, (September 2009), ISSN 0196-9781

vom Saal, F. S.; Cooke, P. S.; Buchanan, D. L.; Palanza, P.; Thayer, K. A.; Nagel, S, C.; Parmigiani, S. \& Welshons, W. V. (1998) A physiologically based approach to the study of bisphenol A and other estrogenic chemicals on the size of reproductive organs, daily sperm production, and behavior. Toxicology and Industrial Health, Vol.14, No.1-2, (January-April 1998), pp. 239-260, ISSN: 0748-2337

Vos, J. G.; Dybing, E.; Greim, H. A.; Ladefoged, O.; Lambré, C.; Tarazona, J. V.; Brandt, I. \& Vethaak, A. D. (2000) Health effects of endocrine-disrupting chemicals on wildlife, with special reference to the European situation. Critical Reviews in Toxicology, Vol.30, No.1, (January 2000), pp. 71-133, ISSN 1040-8444

Waring, R. H. \& Harris, R. M. (2005) Endocrine disrupters: a human risk? Molecular and Cellular Endocrinology, Vol.244, No.1-2, (December 2005), pp. 2-9, ISSN 0303-7207

Watson, C. S.; Alyea, R. A.; Jeng, Y. J. \& Kochukov, M. Y. (2007) Nongenomic actions of low concentration estrogens and xenoestrogens on multiple tissues. Molecular and Cellular Endocrinology, Vol.274, No.1-2, (August 2007), pp. 1-7, ISSN 0303-7207

Watson, C. S.; Bulayeva, N. N.; Wozniak, A. L. \& Finnerty, C. C. (2005) Signaling from the membrane via membrane estrogen receptor-alpha: estrogens, xenoestrogens, and phytoestrogens. Steroids, Vol.70, No.5-7, (May-June 2005), pp. 364-371, ISSN 05852617

Watson, C. S.; Jeng, Y. J. \& Guptarak, J. (2011) Endocrine disruption via estrogen receptors that participate in nongenomic signaling pathways. Journal of Steroid Biochemistry and Molecular Biology, (February 2011), doi:10.1016/j.jsbmb.2011.01.015, ISSN 09600760

Welsh, M.; Saunders, P. T.; Fisken, M.; Scott, H. M.; Hutchison, G.R.; Smith, L.B. \& Sharpe, R. M. (2008) Identification in rats of a programming window for reproductive tract masculinization, disruption of which leads to hypospadias and cryptorchidism. Journal of Clinical Investigation, (April 2008), Vol.118, No.4, pp. 1479-1490, ISSN 0021-9738

Welshons, W. V.; Nagel, S. C. \& vom Saal, F. S. (2006) Large effects from small exposures. III. Endocrine mechanisms mediating effects of bisphenol A at levels of human exposure. Endocrinology, Vol.147, Suppl.6, (June 2006),pp. S56-69, ISSN 0013-7227

West, M. C.; Anderson, L. ; McClure, N. \& Lewis, S. E. (2005) Dietary oestrogens and male fertility potential. Human fertility (Cambridge),Vol.8, No.3, (September 2005), pp. 197-207, ISSN 1464-7273

Williams, K.; McKinnell, C.; Saunders, P. T.; Walker, M.; Fisher, J. S.; Turner, K. J.; Atanassova, N. \& Sharpe, M. (2001) Neonatal exposure to potent and environmental oestrogens and abnormalities of the male reproductive system in the rat: evidence for importance of the androgen-oestrogen balance and assessment of the relevance to man. Human Reproductive Update, Vol.7, No.3, (May-June 2001), pp. 236-247, ISSN 1355-4786

Wilson, V. S.; Blystone, C. R.; Hotchkiss, A. K.; Rider, C. V. \& Gray, L. E. Jr. (2008) Diverse mechanisms of anti-androgen action: impact on male rat reproductive tract development. International Journal of Andrology, Vol.31, No.2, (April 2008), pp. 178187, ISSN 0105-6263 
Wilson, V. S.; Lambright, C. R.; Furr, J. R.; Howdeshell, K. L. \& Gray, L. E. Jr. (2009) The herbicide linuron reduces testosterone production from the fetal rat testis during both in utero and in vitro exposures. Toxicology Letters, Vol.186, No.2, (April 2009), pp. 73-77,ISSN 0378-4274

Wilson, V. S.; Lambright, C.; Furr, J.; Ostby, J.; Wood, C.; Held, G. \& Gray, L. E. Jr. (2004) Phthalate ester-induced gubernacular lesions are associated with reduced insl3 gene expression in the fetal rat testis. Toxicology Letters, Vol.146, No.3, (February 2004), pp. 207-215, ISSN 0378-4274

Winder, C. (1989) Reproductive and chromosomal effects of occupational exposure to lead in the male. Reproductive Toxicology, Vol.3, No.4, pp. 221-233, ISSN 0890-6238

Wolf, C. J.; LeBlanc, G. A.; Ostby, J. S. \& Gray, L. E. Jr. (2000) Characterization of the period of sensitivity of fetal male sexual development to vinclozolin. Toxicological Sciences Vol.55, No.1, (May 2000), pp. 152-161, ISSN 1096-6080

Wong, C.; Kelce, W. R.; Sar, M. \& Wilson, E. M. (1995) Androgen receptor antagonist versus agonist activities of the fungicide vinclozolin relative to hydroxyflutamide. Journal of Biological Chemistry, Vol.270, No.34, (August 1995), pp. 19998-20003, ISSN 00219258

Wozniak, A. L.; Bulayeva, N. N. \& Watson, C. S. (2005) Xenoestrogens at picomolar to nanomolar concentrations trigger membrane estrogen receptor-alpha-mediated $\mathrm{Ca} 2+$ fluxes and prolactin release in GH3/B6 pituitary tumor cells. Environmental Health Perspectives, Vol.113, No.4, (April 2005), pp. 431-439, ISSN 0091-6765

Yoon, K.; Pallaroni, L.; Stoner, M.; Gaido, K. \& Safe, S. (2001) Differential activation of wildtype and variant forms of estrogen receptor alpha by synthetic and natural estrogenic compounds using a promoter containing three estrogen-responsive elements. Journal of Steroid Biochemistry and Molecular Biology, Vol.78, No.1, (July 2001), pp. 25-32, ISSN 0960-0760

Yoshida, M.; Katsuda, S.; Takenaka, A.; Watanabe, G.; Taya, K. \& Maekawa, A. (2001) Effects of neonatal exposure to a high-dose p-tert-octylphenol on the male reproductive tract in rats. Toxicology Letters, Vol.121, No.1, (April 2001), pp. 21-33, ISSN 0378-4274

You, L.; Casanova, M.; Archibeque-Engle, S.; Sar, M.; Fan, L. Q. \& Heck, H. A. (1998) Impaired male sexual development in perinatal Sprague-Dawley and Long-Evans hooded rats exposed in utero and lactationally to p,p'-DDE. Toxicological Sciences, Vol.45, No.2, (October 1998), pp. 162-173, ISSN 1096-6080

Zhang, M.; He, Z.; Wen, L.; Wu, J.; Yuan, L.; Lu, Y.; Guo, C.; Zhu, L.; Deng, S. \& Yuan, H. (2010) Cadmium suppresses the proliferation of piglet Sertoli cells and causes their DNA damage, cell apoptosis and aberrant ultrastructure. Reproductive Biology and Endocrinology,Vol.8: 97, (August 2010), ISSN 0196-9781 


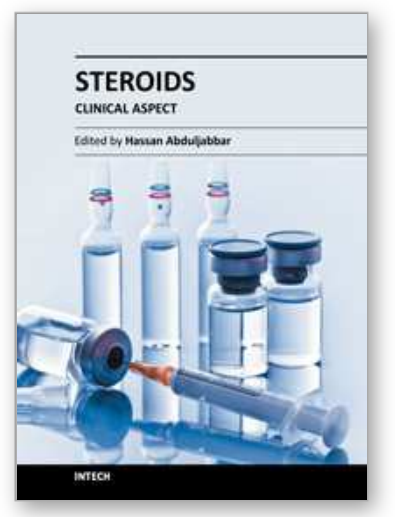

\author{
Steroids - Clinical Aspect \\ Edited by Prof. Hassan Abduljabbar
}

ISBN 978-953-307-705-5

Hard cover, 166 pages

Publisher InTech

Published online 19, October, 2011

Published in print edition October, 2011

Steroids: The basic science and clinical aspects covers the modern understanding and clinical use of steroids. The history of steroids is richly immersed and runs long and deep. The modern history of steroids started in the early 20th century, but its use has been traced back to ancient Greece. We start by describing the basic science of steroids. We then describe different clinical situations where steroids play an important role. We hope that this book will contribute further to the literature available about steroids and enables the reader to further understand this interesting and rapidly evolving science.

\title{
How to reference
}

In order to correctly reference this scholarly work, feel free to copy and paste the following:

Anna Hejmej, Małgorzata Kotula-Balak and Barbara Bilińska (2011). Antiandrogenic and Estrogenic Compounds: Effect on Development and Function of Male Reproductive System, Steroids - Clinical Aspect, Prof. Hassan Abduljabbar (Ed.), ISBN: 978-953-307-705-5, InTech, Available from:

http://www.intechopen.com/books/steroids-clinical-aspect/antiandrogenic-and-estrogenic-compounds-effecton-development-and-function-of-male-reproductive-syst

\section{INTECH}

open science | open minds

\section{InTech Europe}

University Campus STeP Ri

Slavka Krautzeka 83/A

51000 Rijeka, Croatia

Phone: +385 (51) 770447

Fax: +385 (51) 686166

www.intechopen.com

\section{InTech China}

Unit 405, Office Block, Hotel Equatorial Shanghai

No.65, Yan An Road (West), Shanghai, 200040, China

中国上海市延安西路65号上海国际贵都大饭店办公楼405单元

Phone: +86-21-62489820

Fax: $+86-21-62489821$ 
(C) 2011 The Author(s). Licensee IntechOpen. This is an open access article distributed under the terms of the Creative Commons Attribution 3.0 License, which permits unrestricted use, distribution, and reproduction in any medium, provided the original work is properly cited. 